\title{
SOCIEDADES SUSTENTÁVEIS E EDUCAÇÃO AMBIENTAL NA ESCOLA INDÍGENA PATAXÓ DA RESERVA DA JAQUEIRA
}

\author{
Lívia Seymour Galama ${ }^{1}$ \\ Alessandra Buonavoglia Costa Pinto² \\ Angela Maria Garcia ${ }^{3}$
}

Resumo: Este trabalho pretende compreender as ações educativas de caráter socioambiental da Escola Indígena Pataxó da Reserva da Jaqueira (Porto Seguro, BA), tentando correlacioná-las com o conceito de Educação Ambiental (EA) crítica. Utilizou-se a observação participante e o diário de campo como métodos para a coleta de dados, além da interpretação do conteúdo da produção literária indígena Pataxó encontrada na biblioteca da escola. Pôde-se perceber que as atividades da Escola Indígena Pataxó da Reserva da Jaqueira possuem características da EA crítica na maioria das suas ações dentro e fora de sala de aula, caracterizando-se como emancipatórias. Contudo, também ficou claro que essas ações precedem os conceitos de EA crítica.

Palavras-chave: Educação Ambiental Crítica, educação indígena, Pataxó.

Abstract: This work intends to understand the social and environmental educational actions of the Pataxó Indigenous School of the Jaqueira Reserve (Porto Seguro, BA), trying to correlate them with the concept of critical environmental education (EE). Participant observation and field diary were used as methods for data collection, in addition to the interpretation of the content of the Pataxó indigenous literary production found in the school library. It could be seen that the activities of the Pataxó Indigenous School of the Jaqueira Reserve have critical EE characteristics in most of its actions inside and outside the classroom, characterized as emancipatory. However, it was also clear that these actions precede the concepts of critical EA.

Keywords: Critical Environmental Education; Indigenous Education; Pataxó.

1UFSB. E-mail: liviagalama@gmail.com. Link para o Lattes: http://lattes.cnpq.br/1184460945173425

2 UFSB. E-mail: alegubcp@gmail.com. Link para o Lattes: http://lattes.cnpq.br/2365706051026225

3 UFSB. E-mail: angelagarciaufsb@gmail.com. Link para o Lattes: http://lattes.cnpq.br/1512129633145739 


\section{Introdução}

Esta pesquisa observou as ações socioeducativas ambientalistas da Escola Indígena Pataxó da Reserva da Jaqueira para correlacioná-las com as ideias da Educação Ambiental crítica. A intenção é contribuir com os debates e os questionamentos sobre as variadas formas de se pensar a Educação Ambiental (EA) considerando a diversidade do contexto cultural na qual foi desenvolvida. Dessa forma, a intenção do recorte da pesquisa, ao falar sobre educação indígena e EA crítica, é elucidar a urgência do debate das questões indígenas, uma vez que a prática socioeducativa ambiental dos povos indígenas precede o discurso e a prática da EA crítica. Contudo, em linhas gerais, ambos os discursos se aproximam ao se preocuparem com a manutenção do meio ambiente e da diversidade cultural para as gerações futuras.

Assim, para aproximar o discurso da educação indígena e o da EA crítica, torna-se necessário refletir sobre os variados conceitos de educação no contexto das vivências dos povos indígenas. Ao se falar em educação indígena, duas vertentes podem ser inicialmente citadas. Primeiro, o conceito de educação indígena dentro da instituição escolar e, em seguida, a educação misturada com a vida (BRANDÃO, 1981, p. 4). De toda forma, para compreender melhor a educação indígena dentro e fora da escola, nosso olhar primeiro precisa estar voltado para o povo Pataxó da Reserva da Jaqueira.

Nitynawã Pataxó é uma das fundadoras e líderes da Reserva da Jaqueira. Assim, a líder Nitynawã e suas irmãs Jandaya e Nayara criaram um espaço onde poderiam vivenciar o modo de vida dos seus antepassados, preservando a floresta e buscando uma alternativa econômica para o povo Pataxó (PATAXÓ, 2011). De acordo com Nitynawã (2011), somente os Pataxó podem contar a própria história, então, me insiro nessa pesquisa enquanto uma aliada da causa indígena. $O$ intuito desta pesquisa é o desenvolvimento do diálogo, além de contar minhas vivências em campo. Não pretendo tentar explicar a cultura à qual eu não pertenço, pois, como Nitynawã (2018, p. 7) esclarece, a história da Reserva da Jaqueira deve ser contada na visão de quem vive o dia a dia como Pataxó. Sendo assim, de acordo com autora, falar sobre a Reserva da Jaqueira é uma "ciência pessoal", uma vez que essa história escrita se desenvolve a partir das próprias observações, experiências e anotações de Nitynawã enquanto uma liderança Pataxó.

Partindo dessa perspectiva, duas produções literárias de Nitynawã Pataxó foram imprescindíveis para a construção e a contextualização desta pesquisa, As guerreiras na História Pataxó (2011) e Histórias da Reserva da Jaqueira: experiências de autogestão em etnoturismo (2018). Através das produções literárias Pataxó e das observações em diário de campo (como será explicado na Metodologia), a pesquisa pôde ser desenvolvida em uma tentativa de usar a própria fala do povo Pataxó para contar a história da Reserva da Jaqueira, do desenvolvimento da educação indígena e da formação da Escola Indígena Pataxó da Reserva da Jaqueira. 
De acordo com Nitynawã (2011), antes do contato com o homem branco, o povo Pataxó era livre e sadio. Retirava o sustento das raízes, frutos, caças, peixes e mariscos. Andavam em grupos de um lugar para o outro, pois eram nômades. "Toda floresta era nossa casa, porque a terra para nós não tinha divisão" (NITYNAWÃ, 2011, p. 16). Segundo a autora, os Pataxó chegaram a ocupar desde os rios da região de Porto Seguro, no extremo sul da Bahia, até o rio São Matheus, no norte do Espírito Santo. Contudo, os autores viajantes só relataram conhecimento do povo Pataxó a partir do século XIX, ou seja, nos documentos escritos pelo homem branco a partir do início da história da invasão dos portugueses em terras brasileiras não havia registro sobre o povo Pataxó antes do século XIX.

Sobre a Reserva da Jaqueira, segundo Nitynawã (2018), no dia primeiro de agosto de 1997, o cacique Karajá, juntamente com outras lideranças Pataxó e com membros da comunidade, entrou pacificamente na área da Reserva da Jaqueira. A autora conta que na área existia uma jaqueira tombada em cujo tronco nasceram brotos que cresceram e frutificaram. Assim, o frutificar dessa jaqueira tombada foi tomado como uma metáfora para o processo de reconstrução do povo Pataxó que estava acontecendo naquele lugar. Nitynawã (2018, p. 15) conta: "por isso, fizemos uma comparação com as nossas vidas interligadas aos nossos ancestrais e então, surgiu a Reserva da Jaqueira".

Dessa forma, acompanhando o relato da Nitynawã sobre o processo de desenvolvimento da Reserva da Jaqueira, em outubro de 1997, houve a posse definitiva da área conforme registro da demarcação da Terra Indígena Pataxó Coroa Vermelha. Segundo o Projeto Político Pedagógico (PPP, 2010) da Escola Indígena Pataxó da Reserva da Jaqueira, a Aldeia Indígena Pataxó foi fundada no ano de 1997, está localizada no território Indígena Pataxó gleba B, situada no Município de Porto Seguro, na Bahia. A área possui cerca de 827 hectares de mata atlântica primária e secundária, sendo limitada por dois rios, o rio Tinga e o rio Jardim.

De acordo com o PPP (2010), com o crescimento da comunidade houve a necessidade de criar uma escola, e as lideranças buscaram a Prefeitura de Porto Seguro para conseguir esse objetivo. Assim, no dia três de março de 2008 foi fundada a primeira Escola Indígena Pataxó da Jaqueira. Sua inauguração aconteceu no dia primeiro de agosto de 2009.

A fundação da Escola Indígena Pataxó da Reserva da Jaqueira foi vista como um marco para a história da Reserva da Jaqueira. Para compreender esse marco, faz-se necessário entender como a educação é desenvolvida dentro da escola. A palavra "educação" possui diferentes conceitos, dependendo do ambiente em que está inserida. Essa variedade diz respeito à diversidade cultural e social na qual a escola e sua metodologia pedagógica atuam. Além disso, existe certa diferenciação entre os termos "educação indígena" e "educação escolar indígena".

Para começar o debate sobre os diferentes tipos de educação, incluindo 
se entende como educação em um contexto geral. De acordo com Brandão (1981), educação é tornar comum aquilo que é comunitário como bem, como trabalho ou como vida. Além disso, Brandão ressalta que não existe uma única forma nem um único modelo de educação, pois a educação existe em cada categoria de sujeitos de um povo. Dessa forma, segundo o autor, ela também pode existir como uma imposição de um sistema centralizado de poder, que usa o saber e o controle sobre o saber como armas para reforçar a desigualdade entre os seres humanos.

Entramos, agora, no debate sobre educação escolar indígena. Como Brandão salientou, a educação pode ser usada como um instrumento de controle, e esse conceito alcança o que se entende como educação escolar indígena. Para realizar uma breve contextualização sobre o debate em torno das formas de educação escolar indígena desenvolvidas, o autor Scandiuzzi (2008) cita o Maher (1991) para explicar quatro modelos de educação indígena, dentre os quais alguns não corroboram para o fortalecimento da alteridade indígena, pois continuam sendo modelos tradicionais de educação com algumas inserções das questões indígenas.

O primeiro modelo é a educação elaborada pelos próprios indígenas, que os torna cidadãos do mundo ao qual eles pertencem. Esse modelo não se refere ao escolar previsto em legislação, mas, sim, ao modo de vida de cada etnia. Nos outros modelos, há uma intervenção da educação dos brancos. 0 segundo é o "programa de submissão", que acarreta a destruição do referencial linguístico. O terceiro é o "programa de transição", que tem como principal objetivo a aquisição plena da língua nacional e, em segundo plano, a língua indígena. $\mathrm{O}$ autor cita como exemplo desse programa o Referencial Curricular Nacional para a Escola Indígena (1998). Por último está o "programa de desenvolvimento equitativo", no qual há um esforço para que haja um igual desenvolvimento de ambas as línguas, ou seja, a língua portuguesa é vista como um acréscimo ao repertório linguístico dos indígenas.

Contudo, a partir da minha observação em campo, é possível afirmar que, mesmo que exista uma legislação para uma escola específica e diferenciada, e mesmo que a educação escolar indígena siga um programa de desenvolvimento equitativo, se o povo indígena não exercer sua alteridade e colocar como prioridade o ensino da própria cultura para as gerações futuras, a escola pode acabar repetindo alguns modelos tradicionais de seriação da educação.

De acordo com D'Angelis (2008), o problema principal é a seriação, que pode acarretar a evasão escolar, uma vez que as famílias indígenas não veem sentido em dar continuidade às "intermináveis" séries. A seriação também é reforçada através da exigência de disciplina e do cumprimento de horários.

Por outro lado, a educação indígena fora da escola é o modelo exposto por Brandão (1981), no qual ela se instala dentro de um domínio propriamente humano de trocas: de símbolos, de intenções, de padrões, de cultura e de relações de poder, como pode ser observado em um trecho do meu diário de

revista brasileira educação ambiental 
campo no qual observo a fluidez do ensino na aula de patxohã, ministrada pelo próprio cacique. É possível notar a preocupação com a relação de poder e com a troca de símbolos no fato de que é o cacique quem realiza a aula da língua do povo Pataxó.

A aula de patxohã ocupa um dia inteiro para a turma, e não somente um horário de 50 minutos. Vale lembrar também que as aulas não seguem um ritmo padrão de horários de 50 em 50 minutos, elas demonstram ser mais fluidas e orgânicas, seguindo o ritmo de aprendizado dos alunos. Vejo isso como algo positivo, pois tira o mecanicismo da aprendizagem. Os alunos junto com o professor ditam o ritmo da aula, e não um sistema (Diário de campo, 7 de maio de 2019, "Aula de Patxohá").

De acordo com o PPP da Escola Indígena Pataxó da Reserva da Jaqueira (2010), a função da educação escolar indígena é ajudar as comunidades indígenas a compreenderem a sociedade em transformação. $O$ documento escolar salienta a preocupação com a escolha dos caminhos educacionais mais conscientes, fugindo de conceitos difusos cheios de preconceitos e desinformação divulgados pelos meios de comunicação e pela população em geral. Dessa forma, o PPP (2010) reitera que a educação escolar indígena propõe uma visão de desenvolvimento humano associado às atividades sociais e culturais da comunidade em que está inserida. Além disso, observa que essa educação "procura aplicar o conhecimento teórico sobre a complexa realidade que os cerca para que se possa transformar o período de intensas e rápidas mudanças pelo qual passamos, sem que, se esqueça a forma de vida convencional e a realidade existente" (PPP, 2010, p. 9).

A partir do PPP observa-se como o povo Pataxó é consciente das transformações que uma comunidade pode desenvolver dentro de uma realidade complexa na qual se inserem as relações humanas. O PPP deixa claro, portanto, que a abordagem adotada pela educação escolar indígena é a sociocultural, pois há preocupação com o fortalecimento das tradições indígenas, sem deixar de lado, contudo, os problemas do mundo atual.

O documento afirma também que a criança indígena aprende experimentando, vivendo o dia a dia da aldeia e, acima de tudo, acompanhando a vida dos mais velhos. De acordo com o PPP, "na educação escolar indígena 'criança significa herdeiro: levando conhecimento de geração a geração', os professores índios que também são pais, lideranças, moram e participam do cotidiano das aldeias" (PPP, 2010, p. 12). Dessa forma, fica claro que existe uma ligação entre parentesco, instituição de ensino e meio no qual essas crianças vivem e se desenvolvem.

Ao compreender as primeiras diferenciações entre educação escolar indígena e educação indígena percebe-se, então, que, se a educação indígena não se inserir na educação escolar indígena, pode haver uma seriação 
diferenciada da educação proposta. Dessa maneira, a escola indígena poderá perpetuar conceitos que fogem da cosmologia indígena.

Passando para o conceito de EA crítica, considero necessário para a compreensão dessa ideia refletirmos sobre alguns expostos trazidos por Loureiro (2007). O autor afirma que a EA vem sendo adjetivada de várias formas, pois esse campo foi formado por diversas visões de mundo em diálogo e disputa. Por isso, a identidade acabou se definindo mais pela negação à vida urbanoindustrial e aos valores culturais individualistas e consumistas do que por pontos em comum para propor alternativas.

Ainda segundo Loureiro (2007), a EA crítica que se aproxima de certas abordagens da ecopedagogia e que pode ser caracterizada como transformadora, popular, emancipatória e dialógica tem como marca principal se afirmar como uma prática social, assim como tudo aquilo que se refere à criação humana na história: "a EA necessita vincular os processos ecológicos aos sociais na leitura de mundo na forma de intervir na realidade e de existir na natureza" (LOUREIRO, 2007, p. 67).

Seguindo as explicações do autor, a perspectiva crítica aparece quando entendemos que

não há leis atemporais, verdades absolutas, conceitos sem história e educação fora da sociedade, mas, relações em movimento no tempo-espaço e características peculiares a cada formação social que devem ser permanentemente questionadas e superadas para que se construa uma nova sociedade vista como sustentável (LOUREIRO, 2007, p. 67).

Sendo assim, pode-se questionar como os conceitos de EA crítica se correlacionam com as atividades de caráter socioambiental desenvolvidas dentro de uma escola indígena?

A partir da questão-problema desta pesquisa, o objetivo geral foi desenvolvido: correlacionar as ações socioeducativas ambientalistas da Escola Indígena Pataxó da Reserva da Jaqueira com as ideias da Educação Ambiental crítica. Apresentam-se os seguintes objetivos específicos: descrever a trajetória histórica e socioeducativa ambiental da comunidade da Reserva da Jaqueira; identificar atividades didáticas e lúdicas que promovam o pensar crítico em compasso com o conceito de Educação Ambiental crítica; verificar quais ações socioambientalistas desenvolvidas pela Escola Indígena Pataxó da Reserva da Jaqueira promoveram e/ou promovem transformações na realidade local.

Em linhas gerais, como forma de iniciar o debate sobre EA crítica e as atividades desenvolvidas na Escola Indígena Pataxó da Reserva da Jaqueira, o discurso de Loureiro se aproxima dos pressupostos trazidos pelo PPP da escola. No Projeto Político Pedagógico, menciona-se a importância da abordagem sociocultural, uma vez que a sociedade é complexa e o desenvolvimento 
humano está associado às atividades sociais e culturais de sua comunidade, que passam por rápidas transformações.

A abordagem sociocultural escolhida pela escola tem como objetivo possibilitar a formação do sujeito crítico que participa dessas transformações. De forma similar, como foi citado, Loureiro explana que não há leis atemporais, mas que as relações estão em movimento no tempo-espaço. Ou seja, a escola preocupa-se com o desenvolvimento desse sujeito crítico, apto a questionar tais transformações, entendendo a melhor forma de adaptá-las ou não. Voltando a Loureiro, o autor conclui o pensamento explicando que, através da formação do sujeito crítico, é possível desenvolver uma sociedade sustentável. Nesse ponto, deve-se salientar que o desenvolvimento de sociedades sustentáveis é uma característica das práticas da cultura indígena.

Compreendo que há uma diferenciação entre esses dois discursos. Enquanto a EA crítica, em determinados aspectos, vê a construção da sociedade sustentável como um objetivo e uma consequência de uma postura crítica, os povos indígenas observados e estudados nesta pesquisa são, a partir da reconstrução de sua cultura, uma sociedade sustentável, uma vez que também partiram de um pensamento crítico e se reconstruíram a partir do que já era deles, a cultura indígena.

Para reforçar a compreensão sobre os conceitos centrais trazidos por essa pesquisa, retomaremos o discurso sobre EA crítica a partir dos escritos de outros autores. De acordo com os expostos de Sauvé (2005, p. 317), nos quais a EA crítica é entendida como a análise das dinâmicas sociais que se encontram na base das realidades e problemáticas ambientais, as análises dessas dinâmicas abrangem "intenções, posições de argumentos, de valores explícitos e implícitos, de decisões e de ações dos diferentes protagonistas de uma situação." A autora supracitada ressalta que a EA crítica pode contribuir para desconstruir a herança do colonialismo. Dessa forma, torna-se pertinente, uma vez que a EA crítica almeja valores de coletivismo e cooperação, prestar atenção na educação promovida por uma escola indígena, considerando o olhar sensível para as questões socioambientais característico da forma de manejo do meio ambiente dos povos indígenas.

Além disso, pensando também sobre a conceituação de sociedades sustentáveis, de acordo com Carvalho (2008), sociedades sustentáveis podem ser entendidas como aquelas em que o meio ambiente não é reduzido a um conjunto de recursos naturais escassos ameaçados pela sociedade, mas um bem social comum constitutivo da esfera pública. A autora trata, portanto, do que se entende por sustentabilidade forte, na qual se reconhece a finitude dos recursos naturais e a visível desigualdade entre as variadas camadas da população no que diz respeito ao acesso a esses recursos. Deve-se, pois, pensar em uma redistribuição equitativa em termos globais e intergeracionais.

Sobre a localização, a Escola Indígena Pataxó da Reserva da Jaqueira se encontra dentro da Reserva da Jaqueira, localizada no município de Porto Seguro, na Bahia. De acordo com o portal eletrônico do Instituto do Meio 
Ambiente e Recursos Hídricos (INEMA), a Reserva da Jaqueira faz parte da Unidade de Conservação Federal - Área de Proteção Ambiental (APA) Coroa Vermelha. Segundo o INEMA, a APA Coroa Vermelha tem a importância de garantir a preservação dos recursos naturais, ao lado do desenvolvimento de atividades turísticas. A extensão da APA abrange uma área de 4.100 hectares e está localizada no Extremo Sul do Estado da Bahia, nas áreas de parte da zona costeira dos municípios de Santa Cruz Cabrália e Porto Seguro. Por isso, a Reserva da Jaqueira, mesmo localizada no município de Porto Seguro, faz parte da APA Coroa Vermelha. Seguindo os dados fornecidos pelo INEMA, o local apresenta grande fragilidade ambiental, apesar de abrigar grande diversidade de espécies de fauna e flora. Além disso, de acordo com o portal, nas grandes extensões da planície litorânea há a vegetação de restinga, além de remanescentes de Mata Atlântica, a exemplo da Reserva da Jaqueira.

Dessa forma, a escola se encontra no meio de uma área de conservação ambiental fortalecida e assistida a partir da demarcação da terra indígena. De acordo com o portal eletrônico Terras Indígenas no Brasil, o povo Pataxó faz parte da Terra Indígena (TI) Coroa Vermelha. Segundo o portal, o número populacional do povo Pataxó é estimado em cerca de 1546 pessoas em uma área de aproximadamente mil hectares. A TI Coroa Vermelha está homologada e registrada no Cartório de Registro de Imóveis (CRI) e na Secretaria do Patrimônio da União (SPU), de acordo com o decreto s/n do dia 10 de julho de 1998.

Ao realizar a leitura de uma escola indígena, percebe-se que existem costumes e formas de interação desenvolvidos a partir da construção de valores de sua etnia que são perpetuados no ambiente escolar. Por isso, qualquer observação de povos indígenas, independentemente da ênfase, deve ser realizada com olhar vivo sobre sua história e sobre a construção de sentido dos seus costumes e cotidiano. Uma vez que possuem forma característica de interagir e ler o mundo, só assim é possível compreendê-los melhor.

A partir da discussão sobre a genealogia do racismo (MACAGNO, 2014), uma questão importante para compreender a contextualização históricosocioambiental da Jaqueira é refletir a respeito da construção social que são as culturas indígenas. Assim, deve-se fugir de conceitos gerais disseminados a respeito dos povos indígenas, em que se acredita em uma espécie de pureza irreal que encaixota os indígenas em representações caricatas. Faz-se necessário compreender que os povos também fazem parte de uma construção e invenção social. Fugir do pensamento simplista em torno do multiculturalismo, então, é a melhor saída para não cair em análises preconceituosas. Através da discussão dos escritos de Macagno (2004), pode-se entender que o racismo é algo que pode ser datado e localizado; assim, entendendo sua fonte, ele pode ser desvelado e questionado. Isso posto, é possível apreender que as etnias nascem em contextos históricos definidos, por relações históricas concretas e específicas e, então, assimilar que todos vivemos em um estado de cultura, tornando-se quase impossível viver em um estado de natureza. 
Portanto, é a partir da perspectiva de compreender a diversidade social e cultural da história de construção e reconstrução do povo Pataxó que pretendo desenvolver o debate sobre educação indígena e Educação Ambiental desenvolvidas dentro da Escola Indígena Pataxó da Reserva da Jaqueira.

\section{Material e Métodos}

Com os esforços das organizações indigenistas não governamentais e de movimentos indígenas, a partir da década de 1970 a educação indígena foi regulamentada nas políticas públicas brasileiras, principalmente com a Constituição de 1988, na qual se fizeram valer os direitos do reconhecimento da diversidade cultural e linguística, além da participação na administração pedagógica das escolas indígenas (PORTO; BONIN, 2020). A educação indígena deve ser específica para cada etnia e, a partir da Lei de Diretrizes e Bases da Educação Nacional (LDB) de 1996, os próprios indígenas devem administrar seus projetos político-pedagógicos, atendendo às suas especificidades ao valorizar seus costumes e tradições.

Considerando o projeto político-pedagógico (2010) e as atividades da Escola Indígena Pataxó da Reserva da Jaqueira, pode-se afirmar que a escola preconiza a educação indígena diferenciada que atende às especificidades de sua comunidade, valorizando a interculturalidade e o ensino bilíngue e compreendendo, também, o desenvolvimento de atividades de EA. Contudo, antes de começar essa discussão, pretendo desenvolver a reflexão sobre a metodologia escolhida para a análise e interpretação dos dados colhidos em campo. Considerando a honestidade e a transparência como aspectos primordiais para descrever as escolhas da metodologia, assim como considero essencial apontar expectativas concretizadas e dificuldades apresentadas, pretendo também esclarecer todas as etapas vivenciadas juntamente com o referencial teórico que sustenta a metodologia escolhida.

A metodologia referencia-se no livro Pesquisa social, organizado por Maria Cecília de Souza Minayo (1994), e no livro Avaliação por triangulação de métodos: abordagem de programas sociais, de Minayo et al. (2005), que fala sobre a "teoria da abordagem (o método), os instrumentos de operacionalização do conhecimento (as técnicas) e a criatividade do pesquisador (sua experiência, sua capacidade pessoal e sua sensibilidade)" (MINAYO, 1994, p. 15). O método principal é a observação participante e, como método auxiliar, temos a pesquisa bibliográfica, feita a partir da literatura Pataxó encontrada na biblioteca escolar, além de livros e produções acadêmicas Pataxó; o instrumento de pesquisa é o diário de campo, que contém registros do meu cotidiano enquanto pesquisadora dentro da escola, além de anotações de vários diálogos informais, dos quais foram extraídos dados que se relacionam com a pergunta do projeto. Quanto à criatividade da pesquisadora, eu tinha como suporte minha experiência de sete anos enquanto professora de Ensino Infantil, Fundamental I e II no ensino formal em escolas particulares, além da minha experiência no ensino não formal em 
ações educativas em galerias de arte, da minha formação acadêmica em artes com caráter interdisciplinar e da minha curiosidade sobre o assunto pesquisado.

Este trabalho de campo compartilha das ideias da autora do livro Pesquisa social, segundo a qual é necessária a aproximação do pesquisador da realidade sobre a qual formulou a pergunta, para, assim, formar uma "interação com os 'autores' que conformam a realidade" (MINAYO, 1994, p. 62). Dessa forma, constrói-se conhecimento empírico para a pesquisa. Ao citar Malinowski (1984), a autora apresenta os seguintes dados - que foram observados neste trabalho - para a inserção do pesquisador na realidade empírica: estudos de referenciais teóricos, feitos antes do trabalho de campo, para compor uma bagagem científica; observação participante; técnicas de coleta, como o diário de campo ou conversas informais; revisão bibliográfica.

Além disso, essas práticas também estão em compasso com a noção de pesquisa-ação, uma estratégia metodológica de pesquisa social definida por Thiollent (1986), em que a pesquisa social está em estreita associação com uma ação ou com a resolução de um problema, e os participantes da situação estão envolvidos de modo cooperativo ou participativo.

A pesquisa se baseia também nos conceitos e práticas definidos e exemplificados pelo livro Pesquisa em educação: abordagens qualitativas, de André e Lüdke (1986), no qual também se destaca o processo da observação participante. A observação deve ser feita a partir do planejamento sobre o sujeito de estudo e sobre seus aspectos que deverão ser observados, isso através de contato pessoal e estreito do pesquisador com o fenômeno pesquisado.

Foi consultada a Política Nacional de Educação Ambiental (1999), que garante o desenvolvimento da Educação Ambiental nas instituições de ensino como uma prática para a valorização da diversidade cultural. Além dela, foram consultadas também a Política Estadual de Educação Ambiental, (Lei do Estado da Bahia no 12.056/11) e a Política Municipal de Educação Ambiental de Porto Seguro/BA (Lei Municipal $n^{\circ}$ 1.167/14), que preveem a autodeterminação aos povos e comunidades tradicionais, reconhecendo a necessidade de se fortalecerem e garantindo os direitos territoriais, sociais, ambientais, econômicos, culturais e educacionais ao respeitar e valorizar sua identidade, suas formas de organização e suas instituições.

Para contribuir com a coleta de dados, foram utilizados referenciais teóricos produzidos pelos Pataxó, seja no campo da produção literária, seja no campo da produção didática ou acadêmica. Além disso, também foram consultados referenciais bibliográficos de pesquisadores não indígenas como artigos, dissertações e monografias sobre temas que se assemelham ao sujeito estudado ou tratam do mesmo tema.

Considerando a importância do contato aproximado e a participação ativa dentro da comunidade, outros trabalhos que tiveram essa mesma perspectiva de aproximação com o sujeito estudado foram consultados para estabelecer uma preparação para o campo. De acordo com Borges et al. (2021,

revista brasileira educação ambiental 
p. 434), no artigo Educação Ambiental e cultura quilombola: entre ausências de políticas públicas e práticas de resistência, os autores destacam a construção dessa relação em campo em que

Para uma percepção do cotidiano, da cultura e das tradições da população quilombola em estudo, foi necessário estabelecer um relacionamento com alguns sujeitos da comunidade, a fim de favorecer o acesso às histórias de vida e às suas experiências no dia a dia, analisando como os saberes e os fazeres dos remanescentes quilombolas dialogam com a Educação Ambiental, a partir das "Histórias de Vida" (BORGES et al., 2021, p.434).

A partir disso, houve a participação da pesquisadora na rotina da Escola Indígena Pataxó da Jaqueira, conhecendo alunos, professores e funcionários, compreendendo sua cultura através do olhar etnográfico (costumes cotidianos, formas de interação, valores sociais e ecológicos) e internalizando suas vivências, seu cotidiano, seus costumes e formas de interagir com o mundo.

Os encontros aconteceram duas vezes por semana, durante dias letivos das turmas multisseriadas matutinas e vespertinas. As turmas ocupam duas salas de formas arredondadas chamadas de kijemes ("habitação" em Patxohã), sendo uma da pré-escola e a outra do $2^{\circ}$ e do $3^{\circ}$ ano.

Para análise e interpretação de dados, foram adotados os conceitos expostos por Minayo et al. (2005). Dentre as etapas por eles propostas, considerei as seguintes pertinentes ao trabalho: organização do material a partir da forma como foi recolhido e coletado, preparação e reunião de cada material a partir da classificação anterior, avaliação quanto às condições do material e elaboração da estrutura de análise. A partir deste ponto, será conveniente realizar a interpretação qualitativa da análise, articulando-a com fundamentações teóricas.

Como já foi citado, o trabalho de campo desenvolvido por esta pesquisa consistiu na observação participante distribuída em 19 dias letivos dentro do período de 23 de abril a 10 de dezembro de 2019 na Escola Indígena Pataxó da Reserva da Jaqueira, totalizando cerca de 136 horas de atividades de pesquisa de campo. No início da observação, foi determinado com a coordenadora da escola que eu estaria presente em dois dias fixos toda semana; contudo, a partir do segundo semestre, devido às atividades dos componentes curriculares do programa de mestrado, e na medida em que já estava bem adaptada ao campo, comecei a frequentar a escola em qualquer dia viável, sem que eu perdesse a constância da minha presença durante aquele ano.

Logo no primeiro dia de campo dentro da escola, percebi que fui muito bem acolhida, pois os professores não demonstraram nenhuma resistência à minha presença e nem me fizeram muitas perguntas quanto ao meu trabalho. 
Fui informada de que a coordenadora já havia se reunido com os professores logo após o nosso encontro, então eles já estavam cientes do que eu estaria fazendo por lá. Desde o momento em que me inseri em campo, tentei ser o mais participativa possível. Enquanto estava em sala de aula com o professor ou a professora, acompanhava as atividades fazendo pequenas tarefas que os próprios professores me designavam, ou então auxiliava os alunos em suas atividades. Não havia espaço na escola que me fosse restrito, eu tinha total liberdade para conversar com os funcionários, com os alunos, e para mudar de sala caso precisasse. Estava presente também nos intervalos, participava da alimentação e acompanhava as professoras enquanto assistiam às crianças brincando no campo. Sabiam que eu estava ali para pesquisar, mas não percebi constrangimento quanto às suas atividades, continuaram seu cotidiano normalmente.

Ademais, tentei me ambientar ficando o mais à vontade que me era possível. O meu maior desafio nesse trabalho de campo foi o meu próprio constrangimento de me inserir em um espaço que notoriamente não era meu. Pessoas da escola e da reserva, inclusive, estão inseridas no universo acadêmico, fazendo cursos técnicos, graduações e mestrados, tendo as suas próprias vivências como sujeitos da pesquisa e se posicionando em todos os espaços, o que é essencial para o fortalecimento da alteridade do povo Pataxó. De toda forma, qualquer questão relacionada a grupos sociais que passaram por diversas injustiças e atrocidades no processo colonizador do Brasil deveria ser do interesse de todos que têm senso de responsabilidade ambiental, político e histórico. Por isso, tentei superar a minha própria sensação de inadequação tentando me colocar como curiosa, aprendiz, agregadora e aliada, sem esquecer, contudo, do meu papel de pesquisadora dentro daquele espaço, ou seja, sem me forçar a ser uma "igual". Segundo Minayo (1994), enquanto estamos no processo investigativo, mesmo que estejamos partindo de posições sociais diferentes e assimétricas, tanto o pesquisador quanto o sujeito estudado buscam a compreensão mútua que transcenda o senso comum. "No entanto, o pesquisador nunca deve ser reconhecido como um igual" (MINAYO, 1994, p. 77), o próprio sujeito espera dele uma diferenciação, uma delimitação do próprio espaço, embora sem pedantismos, segredos e mistérios. "O pesquisador em qualquer hipótese tem o ônus da compreensão contextualizada e da interpretação" (MINAYO, 1994, p. 77).

A estratégia que usei, para meu próprio conforto e para o conforto do grupo da escola, foi iniciar conversas nos momentos em que sentia abertura, abordar determinados assuntos quando esses apareciam à tona. Tentei me vestir com roupas confortáveis e simples, também usei chinelos, pois era assim que crianças e professores ficavam na escola. Os menores até tiravam os calçados para entrarem em sala de aula e fazerem suas atividades em círculo. Assim, considerei que, de certa forma, seria uma falta de respeito chegar com uma "bota de pesquisadora" para ficar próxima dessas crianças, pois parecia que eu estava vindo de outro "espaço". 
Durante o período em que fiz a pesquisa de campo tanto no horário matutino quanto no vespertino, pude preencher meu diário de campo da turma matutina durante as horas de almoço; para a turma vespertina, fazia pequenas anotações em alguns intervalos, mas o substancial foi escrito depois que retornava para casa. Considerei uma atitude muito invasiva para professores e alunos ficar sentada fazendo anotações sobre eles enquanto trabalhavam. Além de ser constrangedor tanto para mim quanto para eles, isso poderia inibi-los de continuarem com suas atividades como fazem diariamente.

Em alguns dias, no horário de almoço, também fiquei na biblioteca da escola pesquisando livros que fossem de autoria Pataxó e que pudessem ser dados complementares para ampliar a minha análise e interpretação sobre o contexto histórico, a cosmovisão, os processos pedagógicos escolhidos e a forma de enxergar a escola e a reserva. Além disso, os próprios professores e a coordenadora me forneceram trabalhos acadêmicos de autoria Pataxó para que fossem utilizados durante a pesquisa.

A partir do segundo semestre, quando comecei a frequentar somente o turno vespertino, continuei com a estratégia de anotar as considerações importantes nos intervalos e, assim, completar o diário após retornar para casa. Tive a oportunidade de passar um tempo considerável em campo com eles e de estar presente em muitos momentos importantes do ano letivo, o que me gerou uma quantidade de dados considerável. Estive presente no Dia das Mães, na Semana do Meio Ambiente, em jogos, em rodas de awê, nas atividades fora da sala de aula, em palestras; usei os remédios do pajé, levei meu filho diversas vezes para a escola para participar das atividades, encontrei-me com cobra, porco-do-mato, papagaios, aranhas, diversos tipos de plantas, além de conhecer o cotidiano escolar regular e completo, que foi uma experiência única.

Além disso, outra estratégia utilizada foi o registro em diário de campo das viagens que fiz na van escolar. A partir do segundo semestre, comecei a ir embora da escola com a van escolar, junto com as crianças, professoras e funcionários. A van os levava para as aldeias vizinhas, até chegar em Coroa Vermelha. Nesse momento, me aproximei um pouco mais, participei de muitas conversas, entendi melhor contextos sociais dos alunos e o cotidiano de funcionários.

Vou embora com a van escolar da prefeitura até Cabrália, e lá de Cabrália eu pego um ônibus para ir à minha casa. O que foi muito proveitoso, na verdade. Hoje peguei a van de carona, e a conversa informal entre professores, funcionários e alunos toma conta do ambiente. $\mathrm{O}$ carro percorre toda região interna entre Porto Seguro, Coroa Vermelha e Cabrália, passando por dentro dos bairros e por uma parte da rodovia asfaltada para passar em frente à Novos Guerreiros, depois retorna para dentro dos bairros até chegar em Cabrália.

No caminho as crianças contam casos familiares, mas não entram em detalhes, como festas de aniversários, ficar em 
comércios com os pais e brincadeiras. As professoras e funcionários acham graça, fazem algumas brincadeiras e, pelo tom da conversa, consigo perceber que existe familiaridade e intimidade entre professoras, funcionárias e crianças, parece que todos se conhecem de longa data.

As casas que vejo no caminho e onde as crianças vão ficando são das mais variadas, existem casas que ao meu olhar me parecem precárias, algumas ainda em construção, uma situação diferente das crianças que moram na Jaqueira. O último ponto é Cabrália, onde todos descem e eu caminho para pegar meu ônibus (Diário de campo, 3 de setembro de 2019, "Acompanhando a aula dos menores e a van").

Seguindo os conceitos expostos por Minayo et al. (2005) para análise e interpretação de dados, comecei pela organização, classificando as duas formas de coletas de dados utilizadas em campo: o diário de campo e a pesquisa de material acadêmico e literário Pataxó na biblioteca. O diário de campo foi organizado a partir de observações das práticas do cotidiano em sala de aula, em aulas externas e com a comunidade, além do registro de conversas informais e de considerações pessoais. Quanto ao material de leitura coletado, classifiquei os que foram usados para compreender atividades pedagógicas e didáticas, aqueles utilizados para contextualização histórica e os trabalhos acadêmicos que contextualizavam o cotidiano dentro de uma cosmovisão e analisavam criticamente o processo histórico.

$\mathrm{Na}$ etapa de preparação, digitalizei o diário de campo em ordem cronológica e dei títulos para cada dia registrado, referenciando cada título a partir do acontecimento que considerei mais marcante naquele dia. Dessa forma, facilitei a consulta e a identificação da ordem em que os fatos ocorreram. Segundo Minayo et al. (2005), a análise do diário de campo pode ser tão demorada quanto as transcrições, principalmente para o pesquisador que escolhe usá-lo como registro para os diálogos e para anotações do campo, por isso, sua preparação precisa partir de uma perspectiva teórico-analítica. Quanto à literatura consultada na biblioteca na escola, após completar cada leitura, separei em seções, através de blocos de notas, as páginas com os assuntos que julguei pertinentes. Durante a escrita, correlacionei-os com referenciais teóricos da EA crítica e com atividades praticadas na escola por docente e discentes.

Quanto à etapa de avaliação, considerei necessário realizar uma revisão bibliográfica agregando mais fontes sobre educação indígena, etnicidades, pedagogia, educação crítica e emancipatória, EA crítica, leis e decretos. Além disso, reli todo o diário de campo, realizando uma revisão no que havia sido digitalizado e acrescentando algumas considerações e observações pessoais, o que fez com que iniciasse a relacionar as vivências com a literatura sobre EA crítica.

Revbea, São Paulo, V.16, № 5: 462-499, 2021.

revista brasileira

educação ambiental 
Para a etapa de elaboração de estrutura de análise, que é a construção teórica da pesquisa, as atividades registradas em diário de campo que foram classificadas como de caráter socioambiental e interdisciplinar, juntamente com a literatura analisada e classificada como agregadora às atividades observadas em campo, puderam ser relacionadas com os referenciais teóricos representativos da EA crítica, para que, dessa forma, eu pudesse estabelecer uma interpretação sobre essa correlação e, assim, desenvolver uma argumentação sobre os resultados encontrados.

Dessa maneira, considero contribuir para o debate ambiental a partir da valorização dos saberes dos povos indígenas, além de contribuir com os diálogos sobre outras maneiras de viver, menos predatórias e mais sustentáveis, e de sanar a curiosidade sobre a forma como a educação indígena é conduzida no cotidiano e sua aproximação com conceitos da EA crítica.

A Escola Indígena Pataxó da Reserva da Jaqueira é um reflexo e uma consequência das ações de etnoturismo que acontecem na Reserva da Jaqueira. Para entender o funcionamento da escola e suas atividades educativas ambientais, é preciso, primeiramente, entender o contexto da ação educativa ambiental que acontece dentro da Reserva. De acordo com o portal eletrônico da Funai, o etnoturismo se caracteriza como uma alternativa sustentável de renda para comunidades indígenas.

O etnoturismo é a atividade que a reserva aprendeu e desenvolveu na comunidade para que seja uma forma de segurança e sustento das famílias que ali vivem. Com a consolidação da atividade e da reserva, o local também passou a ser uma rede de apoio para os Pataxó. De acordo com Nitynawã (2018), o ecoturismo (como as atividades eram chamadas no início) era a alternativa econômica viável para o grupo na época, pois, com a proposta de ser um instrumento da conservação ambiental e valorização cultural, garantiria que os Pataxó poderiam vivenciar a cultura e fortalecer a identidade da comunidade. Ao se fortalecerem enquanto povos indígenas com identidade cultural distinta, garantiriam o direito ao território e, com isso, segurança e visibilidade para a comunidade.

Grosso modo, a necessidade de se afirmarem enquanto uma etnia com características próprias surge a partir dos processos históricos e de estudos antropológicos que configuraram os indígenas do Nordeste como remanescentes e misturados. De acordo com Oliveira (1998), a unidade dos indígenas do Nordeste não foi dada por sua história ou por sua conexão com o meio ambiente, mas por pertencerem ao Nordeste enquanto um conglomerado. Além disso, o título de "misturados" tem caráter negativo, dando a entender que não são "puros" e que, por isso, perderam sua cultura, e assim também perderam seus direitos enquanto indígenas. Segundo o autor, isso se explica por uma cadeia de estudos puramente cronológica de fatos históricos sem nenhum esforço de conceituação.

O autor continua a explicação afirmando que, no Nordeste, os indígenas 
de uma forte contrastividade cultural, ou seja, não era imediatamente perceptível que eram indígenas, pois estavam entremeados à população regional e os órgãos indigenistas cuidavam de poucas questões a respeito dessa etnia, tratando em alguns momentos de questões assistencialistas ou questões fundiárias. O autor mostra em seu texto que era necessário que os indígenas do Nordeste reestabelecessem seus territórios, e a maneira como conseguiriam isso seria desnaturalizando a "mistura" como a única via de sobrevivência e cidadania. Assim, é o processo de etnogênese que caracteriza os povos dessa região, uma vez que esse conceito abrange tanto a emergência de novas identidades como a reinvenção de etnias já conhecidas.

Foi dentro dessa perspectiva que uma parte do povo Pataxó se organizou para resgatar um modo de viver ancestral e se fortalecer enquanto povo indígena. Essa primeira parte que se estabeleceu na reserva tem as irmãs Jandaya, Nayara e Nitynawã como pioneiras do desenvolvimento do local, e precisou se educar, aprender, buscar conhecimento e repassá-lo para os demais. Essa busca veio através do resgate dos conhecimentos dos mais velhos, ouvindo as histórias do passado, com o protagonismo dos próprios indígenas. Takwara, a anciã e mãe das irmãs, se mostrou uma fonte de resgate da cultura. Nitynawã (2018) relata que a anciã Takwara é um livro vivo dentro da aldeia, o qual possui todas as disciplinas Pataxó. Nesse trabalho, a autora também relata que, ao longo de sua vida, não viveram somente em uma aldeia, por isso, o contato com outras etnias, como os Maxakali, agregou conhecimentos sobre a terra e a vida, o que, de acordo com autora, os manteve ligados aos "parentes", além de garantir a sobrevivência.

O ponto ao qual pretendo chegar é o fato de que, de certa forma, foi através de atividades com caráter educacional que o povo Pataxó da Jaqueira conseguiu se reestabelecer enquanto povo indígena fortalecido com identidade cultural distinta, ressignificou suas tradições, seja nas vestimentas, seja nos cantos, nas festividades, nos rituais, no grafismo, nos jogos, nas trilhas, no artesanato e nas histórias. Essas ações educativas são marcadas principalmente pelo exercício da oralidade. Observo que a oralidade foi importante para que se organizassem em muitas ações de ressignificação, inclusive para o desenvolvimento do regaste da língua patxohã.

Dessa forma, toda a dinâmica da mobilização desenvolvida para o resgate da cultura indígena Pataxó se aproxima das práticas da EA crítica. De acordo com Silva (2007), a EA crítica privilegia a dimensão política das questões ambientais e apresenta a necessidade do fortalecimento da sociedade civil na busca coletiva de transformações sociais. Para a autora, a EA crítica se apoia na práxis, na qual a reflexão provê a ação e esta carrega novos elementos para a reflexão, ou seja, a EA crítica busca mecanismos para que o indivíduo e a coletividade assumam uma postura reflexiva frente às questões ambientais e descubram elementos para consolidar uma sociedade sustentável.

Esses elementos que caracterizam a EA crítica são perceptíveis no desenvolvimento das pessoas que se mobilizaram para a formação da Reserva

revista brasileira educação ambiental 
da Jaqueira. Essa primeira parte do povo Pataxó da Reserva da Jaqueira, por meio de um pensamento reflexivo sobre as próprias condições sociais, se mobilizou coletivamente em uma postura reflexiva e crítica, e, com atitudes políticas que retiraram uma empreiteira do território indígena, começaram a estabelecer uma sociedade com características sustentáveis por meio de ações de etnoturismo, pensadas e desenvolvidas por eles mesmos.

Nos textos pesquisados que foram escritos por Nitynawã em sua trajetória acadêmica e de vida, fica claro o quanto a educação era importante para ela e sua comunidade. A líder sempre lutou para conquistar a própria educação e a da comunidade em que está inserida, onde esse cuidado com a educação é perpetuado. Ela cita que ela e suas irmãs, aliados e essa parte do povo Pataxó que se estabeleceu na Reserva da Jaqueira estavam sempre transmitindo conhecimentos novos que adquiriam com estudos, encontros com outras etnias e conversas com anciãos, e que, assim, sentiram necessidade de registrar o que aprendiam, fazendo inclusive o registro da língua, que resgatavam nas conversas com os mais velhos. Assim, o grupo, que se encontrava no espaço da cozinha para aprender e educar, foi tomando forma até ser contemplado com o Programa Pontos de Cultura.

De acordo com o site do governo ${ }^{4}$, os Pontos de Cultura são uma base social capilarizada e com poder de penetração nas comunidades e territórios, especialmente nos segmentos mais vulneráveis. Os Pontos de Cultura são uma política cultural com programas sociais do governo e de ministérios que auxiliam novos arranjos econômicos e produtivos, atendendo, assim, a toda uma nova economia que vem sendo inventada e experimentada por aqueles que encontram no fazer cultural uma alternativa de trabalho, vida e inserção social. Hoje, o Ponto de Cultura Pataxó tem um escritório em Coroa Vermelha que auxilia constantemente as ações da Reserva da Jaqueira.

O grupo de Atxohã também foi uma chave importante para que a necessidade de uma escola dentro da Reserva se desenvolvesse. De acordo com o Inventário Cultural Pataxó (2011), o grupo Atxohã foi organizado para a pesquisa da língua e da história Pataxó, sua formação foi incentivada pelos educadores e líderes Pataxó para que fossem organizadores dessa busca histórica do povo Pataxó, começando de forma independente estudos mais detalhados sobre a língua. Foi esse mesmo grupo que começou a chamar a língua de patxohã, sendo 'pat' as iniciais de 'Pataxó'; 'atxohã' significa 'língua'; 'xohã' é 'guerreiro'. Ou seja, "patxohã” pode ser traduzido como "língua de guerreiro". Os estudos começaram em 1998 em Barra Velha e Coroa Vermelha e, após se consolidarem como um grupo de pesquisa em 1999, conseguiram o marco de 2.500 palavras em 2011, quando o livro Inventário da Cultura Pataxó foi publicado.

Desde 2003, estão fazendo um trabalho de reaprendizado da língua nas escolas de Barra Velha e Coroa Vermelha e na Escola da Reserva da Jaqueira.

\footnotetext{
${ }^{4}$ Disponível em: <http://www.antigo.cultura.gov.br/web/guest/pontos-de-cultura1>.
} 
O grupo afirma que o trabalho da língua não deve ser feito somente nas escolas, é preciso valorizá-la, usando-a no dia a dia da comunidade.

Frequentando a escola por um período de 2019, percebo que o ensino da língua Patxohã é algo essencial para o desenvolvimento do aprendizado dos estudantes indígenas, pois se trata de um instrumento fortalecedor da identidade cultural daquele grupo. Todas as turmas possuem um dia específico para a aula de patxohã, e a aula dura todo o período matutino ou vespertino. Como já foi dito, o próprio cacique é o professor, mostrando que a educação faz parte de uma ação coletiva da comunidade.

A escola é regulamentada pela Secretaria da Educação de Porto Seguro, ou seja, os funcionários da escola são regulamentados. Contudo, isso não é suficiente para que a escola se torne um mecanicismo no qual cada um realiza apenas o que lhe é designado e, assim, encerra o expediente. A Escola da Jaqueira está aberta para a comunidade, que está sempre próxima, seja assistindo um pouco das aulas, seja conversando com os alunos, trocando informações com a coordenadora, os professores e funcionários, passando para olhar as atividades naquele andar meio desatento, mas que presta atenção no que está acontecendo. Percebo essas atitudes como um ponto positivo para o desenvolvimento da escola e da sua integração com a comunidade, pois é por isso que ela está ali, bem no meio da reserva.

Segundo o Projeto Político Pedagógico (2010), a escola participa das atividades realizadas na comunidade como uma forma de manter o elo entre escola e comunidade, destacando as roupas tradicionais que alunos e professores usam no dia a dia, além da relação entre aluno e natureza, que os torna parte dela, responsáveis pela sua conservação para gerações futuras. Ainda de acordo com o PPP, a educação escolar indígena procura formar cidadãos críticos e participantes, procurando aplicar o conhecimento teórico sobre a realidade complexa que os cerca. Dessa forma, propõe o desenvolvimento humano associado às atividades sociais e culturais de sua comunidade, ou seja, "as atividades realizadas pelos membros da mesma têm significados em seu contexto social" (PPP, 2010, p. 9).

Pude perceber, em minha observação participante, que esse cuidado com a educação se direciona ao discurso de alteridade, reforçando sua identidade através da língua, da oralidade, dos trajes, dos costumes, e essas ações andam bem alinhadas com a maioria dos participantes da reserva, seja dentro da escola, seja fora dela. Logo no início, em nossa primeira visita, o diretor dos projetos da reserva já nos corrigiu quanto ao uso da palavra "retomada", apesar de ela ser frequentemente encontrada na literatura acadêmica que trata dos povos tradicionais. Segue trecho do diário de campo:

Também conversamos com o diretor executivo e coordenador de projetos da reserva. Conversamos com ele, em sua sala de atendimento, onde houve muitas trocas. Ele nos alertou da importância da devolutiva à reserva quando se trata de projetos 
de mestrado e doutorado, pois muitas vezes os pesquisadores somem sem devolver os resultados para a comunidade. Ele disse também sobre o cuidado de usarmos a palavra retomada, pois eles não estavam retomando nada do que foi perdido. A cultura estava dentro de cada povo indígena, eles estavam resgatando valores que já possuíam, mas que, infelizmente, estavam escondidos devido às circunstâncias de dominação colonial e preconceito com os povos originários que existe no Brasil (Diário de campo, 23 de abril de 2019, título: "Apresentações").

Em outro momento também fiz observações sobre a importância dos trajes tradicionais dentro do espaço da Reserva da Jaqueira e no ambiente escolar:

Outra coisa que chamou minha atenção é que as professoras e os funcionários da escola utilizam a tanga, que é uma espécie de saia feita de piaçava, e o cinto de crochê, indumentárias características do povo da Jaqueira. As vestimentas são usadas normalmente no seu cotidiano, aqui eu percebo que não é uma representação ou uma simulação, e sim algo que faz parte do cotidiano. Achei este elemento importantíssimo para manutenção da cultura, e é passado de geração a geração. Pude perceber que alguns alunos também usam, e os pais dos alunos também usam. Em um primeiro momento, já é perceptível a preocupação com as gerações futuras na preservação da cultura e dos costumes. Assim como pude perceber essa preocupação com a geração futura na aula de matemática, ao se falar sobre as espécies de plantas que existem na Jaqueira, e na professora que já está ensinando sobre os materiais com que se faz um kijeme (Diário de campo, 25 de abril de 2019, título: "Primeiro dia na escola").

A primeira trata-se de uma atividade de matemática para as turmas do $4^{\circ}$ e do $5^{\circ}$ ano que foi realizada dentro do viveiro de plantas, onde os alunos deveriam estimar a quantidade de anos que determinadas espécies levariam para ficarem adultas. Em seguida, foi montada uma escala crescente com essas estimativas, afixando os pedaços de papel com números em um barbante. A segunda atividade refere-se a um cartaz que as crianças da pré-escola fizeram para ilustrar um kijeme, utilizando materiais naturais recolhidos nos arredores da escola, principalmente o barro e a piaçava.

O cuidado com o uso correto das palavras para falar da reconstrução da identidade Pataxó, além da ação cotidiana de manterem seus trajes tradicionais, seja para receber os turistas, mas também para participar das atividades da escola, demonstra o esforço coletivo diário em manter seus costumes dentro do cotidiano da Reserva da Jaqueira. A partir das minhas observações, pude analisar que não é obrigatório o uso dos trajes fora ou dentro da reserva; em 
determinadas situações bem específicas, por exemplo para sair da reserva para resolver alguma questão administrativa ou algo parecido, os Pataxó ficam livres para se vestirem como bem desejarem; não é algo que percebo como imposto, mas, sim, como disse anteriormente, como um esforço coletivo cotidiano. Apesar de ser comum o comentário de que "parecem que se fantasiam para trabalhar como índios", devo dizer que esse é um argumento preconceituoso e errôneo. A partir do que foi observado, até mesmo nas atividades da escola o traje é utilizado como uma estratégia pedagógica de fortalecimento da identidade, e isso também é previsto pelo PPP da escola. Além disso, o ambiente da reserva, como já foi citado nos trabalhos de Nitynawã, é um ambiente em que eles podem vivenciar sua cultura na integridade, sem julgamentos. Além do mais, estamos falando de um povo que se reconstruiu para fortalecer sua identidade dentro de um contexto muito aproximado de sociedades não indígenas. Para isso, é preciso que o grupo use a adaptação a cada ambiente para ocupar os espaços.

Castro (2008), que realizou um trabalho antropológico muito bem desenvolvido na Reserva da Jaqueira, relaciona suas observações com os estudos de Grunewald (2001) e afirma que os Pataxó não admitem são insistentes em afirmar que se trata de um trabalho de resgaste. Ao se referirem a resgate, não o percebem como algo desligado da experiência vivida; "concebem-no como processo contemporâneo, resultado de muito anos de perda e mistura na sociedade regional/nacional" (CASTRO, 2008, p. 117). Ou seja, para os Pataxó engajados nos projetos de resgate cultural, não há dicotomia entre invenção e resgate. A autora observa que, ao falarem das tradições, as falas oscilam entre o presente e o passado, assim, ao concordar com essa oscilação do tempo verbal, as palavras "tradição" e "tradicional" parecem ter dois valores, ora dizem aquilo que fazem em suas rotinas diárias, ora se referem a um tempo passado. A autora conclui sua argumentação alertando para a importância de perceber que o resgate ou invenção das tradições não é colocado por sobre uma história anterior que é anulada. A autora percebe que é exatamente o contrário que acontece, o resgate ou invenção das tradições é pensado no interior mesmo dessa história, pois a ambiguidade da palavra tradição não indica uma alienação em relação a um passado que foi perdido (se referindo às práticas do presente) nem indica que os turistas estão sendo enganados (se referindo às práticas do passado). " $A$ ambiguidade, na verdade, faz projetar sobre a palavra tradição uma história de perdas e de tentativas de recuperação dos modos de vida, da identidade, como também da dignidade" (CASTRO, 2008, p. 118).

Toda essa discussão pode ser inserida dentro do contexto da EA crítica, uma vez que os Pataxó se entenderam enquanto indivíduos e coletivos relacionados mutuamente e, assim, compreenderam a responsabilidade social e ambiental que possuíam enquanto povo indígena e se mobilizaram coletivamente de forma política para transformar positivamente a forma em que viviam para toda uma comunidade. Esse coletivo partiu de ideais democráticos e emancipatórios, através de um pensamento crítico sobre a própria condição social. 
Segundo Carvalho (2004), a EA crítica pode ser entendida como um projeto que pretende transformar a sociedade. Por isso, convoca a educação (ou toda uma ação educativa que pode ser balizada em processos históricos, políticos, entre outros, como vimos na formação da reserva) "a assumir a mediação na construção social de conhecimentos implicados na vida do sujeito" (CARVALHO, 2004, p. 18). A autora afirma que as práticas de EA, seja na área política, seja na pedagógica, produzem culturas ambientais que interferem na maneira como os grupos sociais dispõem dos bens ambientais e imaginam suas perspectivas de futuro. Dentro dessa ótica, pode-se perceber que a organização dos líderes e dos grupos aliados para a formação da Reserva da Jaqueira se alinhou para fortalecer sua identidade através de práticas resgatadas que, além de valorizarem sua cultura e fortalecerem sua identidade, também praticam atividades de características sociais e ambientais.

Fazia-se necessário fazer essa contextualização resumida das práticas da Reserva da Jaqueira para compreender as atividades da Escola da Jaqueira. A escola é um reflexo das atividades que acontecem na reserva. De acordo com Nitynawã (2018), a comunidade da Jaqueira tinha (re)encontrado a própria etnopedagogia no dia a dia, e, assim, perceberam que ficavam mais motivados e fortalecidos (re)descobrindo a interação com a mata e compartilhando os ensinamentos com eles mesmos e com os visitantes através de várias atividades como palestras, trilhas, construção de kijemes, artesanatos e da contação de histórias. Segundo a autora, assim eles se perceberam como pesquisadores e mediadores do etnoconhecimento em relação à Escola/Comunidade. A líder explica que já entendiam o espaço enquanto uma área de transmissão de conhecimento, de construção de cidadania antes mesmo da fundação da escola propriamente dita.

Segundo relatos de Nitynawã (2018), os Pataxó mais jovens começaram a se casar, e assim, as crianças começaram a nascer, fazendo com que grupos que moravam em Coroa Vermelha se mudassem para a Reserva da Jaqueira. As crianças dessas novas famílias precisavam caminhar $12 \mathrm{~km}$ para irem para a escola. O Juari, que então era vice-presidente da Associação Pataxó de Ecoturismo, idealizou a construção de uma escola diferenciada, ou seja, uma escola com educação indígena na qual as crianças não precisariam sair da reserva e aprenderiam o patxohã.

Após muitas idas à Secretaria de Educação de Porto Seguro, o setor de educação indígena acatou o projeto da escola. O próprio Juari elaborou a planta e o projeto de ensino para apresentar à prefeitura e, assim, a escola foi construída pela Secretaria Municipal de Educação, com apoio da Veracel e da Funai, com inauguração em $1^{\circ}$ de agosto de 2008.

Durante a observação participante, através do contato mais estreito com as professoras e os professores, foi possível compreender como eles integram a educação diferenciada indígena com a educação formal. No que diz respeito à educação formal, eles fazem algumas atividades de alfabetização, pois consideram importante para a formação das crianças enquanto cidadãs que 
saibam ler e escrever corretamente, como uma forma primordial de recorrerem aos seus direitos.

No dia 29 de abril de 2019, durante uma aula de Língua Portuguesa da turma matutina do $4^{\circ}$ e do $5^{\circ}$ ano, faço as seguintes observações:

Como a sala tem o formato de um kijeme, que é arredondado, a disposição das cadeiras é em formato de meia-lua. Nesse dia, o professor ministrou sua aula dentro do kijeme, era uma atividade de escrita passada no quadro. Os alunos são incentivados a melhorarem a forma como escrevem, sempre lembrados pelo professor de que eles precisam escrever e ler bem para continuarem com as atividades da comunidade e para desenvolverem pessoalmente (Diário de campo, 29 de abril de 2019, título: "Clima acolhedor na sala de aula").

Nesse mesmo dia, com a turma vespertina do $2^{\circ}$ e do $3^{\circ}$ ano, pude observar uma atitude semelhante da professora:

A professora também reforça para os alunos a importância de saberem ler e escrever corretamente para que possam ter seus documentos de identidade, possam se incluir na sociedade e continuar seus estudos para se desenvolverem pessoalmente e contribuírem com a comunidade. Vejo aqui, mais uma vez, a preocupação de se fortalecerem como cidadãos participantes de uma sociedade política e de passarem esses ideais para as gerações futuras. Percebo aqui uma preocupação com a geração futura, de se incluírem na sociedade de forma integral, e como uma forma de fortalecer a sua comunidade. (Diário de campo, 29 de abril de 2019, título: "Clima acolhedor na sala de aula.")

A interpretação que confiro a essas atividades é que, apesar de não possuírem características de educação indígena à primeira vista, dentro do contexto em que estão inseridas, de uma comunidade que se fortalece nas práticas culturais, mas que também se fortalece com movimentações políticas, através da cobrança de líderes governamentais, ou se inserindo em espaços acadêmicos, as atividades de alfabetização, nas quais as crianças são estimuladas a ler, a se sentar e praticar a escrita tornam-se algo essencial no ambiente escolar. Além disso, a forma como as atividades são contextualizadas para os alunos lhes confere um caráter dialógico sobre a necessidade de se posicionarem enquanto um grupo que desenvolve muitas capacidades para, assim, exercer sua cidadania. Em Pedagogia da autonomia, Freire (1996) salienta que a tarefa coerente do educador é exercer a irrecusável prática de fazer com que o educando produza sua própria compreensão no que vem sendo

Revbea, São Paulo, V.16, № 5: 462-499, 2021.

revista brasileira educação ambiental 
comunicado, ou seja, o educando se sente mais motivado a realizar suas atividades quando consegue compreender a proposta que vem inserida naquela atividade.

De fato, nos momentos em que estive presente na escola, pude perceber muitos elementos da cultura Pataxó da Reserva da Jaqueira inseridos em diversas atividades do cotidiano escolar. Essas inserções, seja as corriqueiras, seja as muito bem-intencionadas, conferiam às ações da escola caráter interdisciplinar, transdisciplinar e emancipatório, além de valorizarem a cultura e de exercitarem a autoestima e o autoconhecimento, exercendo a identidade indígena. Relatarei alguns trechos do diário de campo em que pude observar essas ações e, em seguida, as correlacionarei com os escritos sobre EA crítica, para, assim, concluirmos uma interpretação.

Ainda no dia 29 de abril de 2019, observei os alunos que participavam do awê antes do início da aula:

Na parte da manhã, quando chego à escola, o horário da aula está começando, faz parte do cotidiano da escola cantar o awê antes de iniciar as atividades. $O$ awê é uma dança de roda que faz parte do cotidiano dos Pataxó antes de começarem suas tarefas, para que eles estejam protegidos e abençoados para começar aquele dia. Também pude perceber essa atividade nos encontros dos turistas antes de começar o passeio (Diário de campo, 29 de abril de 2019, título: "Clima acolhedor na sala de aula").

Seguem observações do mesmo dia sobre o horário de intervalo:

As crianças brincam juntas, geralmente com as brincadeiras que acontecem na visita dos turistas, como a corrida de maracá. O maracá é um instrumento parecido com um chocalho que faz um som de percussão. As crianças demonstram muito interesse e gostam muito de segurar e brincar com o maracá. Inclusive, o maracá é utilizado para marcar o tempo, seja porque já deu a hora de a brincadeira acabar, seja para se alimentar ou para retornar aos kijemes (habitação indígena Pataxó na língua patxohã) (Diário de campo, 29 de abril de 2019, título: "Clima acolhedor na sala de aula").

Agora, outra observação sobre a turma menor da pré-escola:

A turma dos menores faz muitas atividades com música e contação de histórias, e eles gostam muito do maracá. A professora os incentiva a falar em patxohã para irem beber água 
ou para irem ao banheiro, e de novo vejo o fortalecimento da cultura de todo um povo e de uma comunidade dentro do ambiente escolar. Percebo aqui a escola fortemente como um instrumento de fortalecimento da cultura Pataxó (Diário de campo, 29 de abril de 2019, título: "Clima acolhedor na sala de aula").

Percebo o esforço na dinâmica didático-pedagógica dos professores para inserirem elementos típicos da cultura Pataxó. Assim, as crianças assimilam essas atividades e objetos, utilizando-os no dia a dia de forma espontânea e natural. Além disso, demonstram apreciar ter a oportunidade de usá-los como algo que Ihes traz uma recompensa positiva. De acordo com Carvalho (2004), a EA crítica solicita à educação a assentir a mediação na construção social de conhecimentos comprometidos com a vida dos sujeitos. Assim, a EA crítica delineia novas racionalidades que constituem os laços identitários de uma cultura, seja na área política, seja na ambiental.

Outro evento marcante que aconteceu num dia em que eu estava presente para observação participante foi um encontro de professores e da coordenadora com os familiares dos alunos. O encontro não foi realizado em salas de reuniões ou conferências, como geralmente acontece em escolas não indígenas, até porque não é necessária a existência de espaços assim na escola. Tampouco o encontro foi realizado dentro de algum kijeme; os familiares se encontraram do lado de fora da escola, rodeado pela vegetação local; aliás, tudo por lá é rodeado pela vegetação local. As famílias chegam descontraídas, algumas vêm de aldeias vizinhas, outras são da Jaqueira e estão vestidos com os trajes tradicionais, não há nenhum estranhamento em relação a isso. A intenção da coordenadora, nesse encontro, era promover a reflexão entre os familiares sobre como era necessário que estivessem juntos no exercício da educação das crianças. Segue trecho do diário de campo:

Os familiares chegam bem à vontade, conversam com os funcionários e participam das arrumações tranquilamente, caso ainda falte alguma coisa para ser colocada no lugar. O professor da turma dos meninos mais velhos passa, na televisão que fica guardada na secretaria, um vídeo com os alunos falando sobre suas famílias e fazendo algumas atividades dentro da escola. Em seguida, a coordenadora realizou uma dinâmica com os familiares que foi muito divertida. Ela pediu para cada familiar encher uma bexiga e escrever o nome do filho nela, quem tivesse mais de um filho teria que encher mais de uma bexiga. Assim, após as bexigas estarem cheias, os familiares deveriam ficar brincando com as bexigas, jogando para cima levemente, aludindo a uma pequena administração da família. Depois, a coordenadora pediu que todos jogassem as bexigas para cima e tentassem pegar mais de uma ao mesmo tempo. Em meio a muitas risadas, os familiares perceberam que era muito difícil 
segurar todas as bexigas ao mesmo tempo. Com essa atividade, a coordenadora explicou que, para a escola, receber todos os alunos e amparar todos sem ajuda dos familiares era uma tarefa muito difícil, por isso pedia que as famílias sempre estivessem presentes na escola. Em seguida, a confraternização encerrou com a distribuição da comida (Diário de campo, 14 de maio de 2021, título: "Festa do Dia das Mães").

Somente pelo fato de essas atividades não estarem inseridas em espaços formais de educação, e sim dentro de uma reserva, no contexto de comunidades indígenas, aproximando escola de comunidade, já se podem perceber ações de caráter emancipatório que vão além do espaço escolar e do contato com os alunos. Carvalho (2004), em seu texto intitulado Educação Ambiental crítica: ideias para este outro mundo possível, traz um tópico que alude bem à atividade que foi citada em diário de campo: "atuar no cotidiano escolar, provocando novas questões de aprendizagem e desafios para a participação na resolução de problemas, buscando articular escola com os ambientes locais e regionais onde estão inseridas" (CARVALHO, 2004, p. 21).

Podemos refletir se todas essas atividades - e aqui não foram citadas todas as que foram observadas - refletem atitudes socioambientais no comportamento e no discurso das crianças. Pude presenciar um momento de diálogo entre uma criança de 5 anos estudante da escola e uma turista que passava pelo ambiente. Antes disso, faz-se necessário explicar que, nas visitas, a escola também é um elemento a ser mostrado, devido ao orgulho que a comunidade tem da sua existência dentro da reserva, e é nesse momento que explicam que lá é ensinado o patxohã para as futuras gerações.

As observações que se seguem foram feitas no dia 21 de maio de 2019, enquanto estava na sala de aula esperando as crianças chegarem para auxiliar a professora nas atividades:

Pela tarde, tem uma criança da turma do pré-escolar (que todos os dias sempre chega mais cedo na escola). Ele é muito agitado e muito livre. Sempre chega andando de bicicleta e fica muito à vontade para conversar. Como ele chega mais cedo, as vezes encontra com turistas que ainda passam pela escola na hora do almoço. A mulher que era turista chegou perto dessa criança com um sorriso, pois estava feliz por estar na Jaqueira e encontrar aquela criança, e disse "você é um indiozinho", no que ele respondeu "eu não sou um indiozinho, o meu nome é ...". Fiquei impressionada com a perspicácia da criança de não se reconhecer de forma diminutiva e acredito já é um reflexo dos trabalhos escolares, feitos juntamente com a comunidade e a família, de fortalecimento da cultura (Diário de campo, 21 de maio de 2019, título: "Cotidiano em sala de aula"). 
O fato de a criança dizer "que não é um indiozinho" não quer dizer que ela não se reconheça como indígena, pois acompanhei de perto essa criança durantes as atividades e não é isso o que acontece. Essa é a mesma criança que falou sobre o barro como um algo importante de sua vida, sendo o barro o elemento principal do mito fundador do povo Pataxó. Ela fala desse elemento natural de acordo com percepções da sua idade e, mesmo assim, já o reconhece enquanto recurso natural de valor histórico e cultural dentro da sua comunidade. Percebo, aqui, que a intenção da turista não era depreciativa, ela falou de forma calorosa e estava demonstrando contentamento por estar perto daquela criança. Contudo, a criança já está se formando enquanto um sujeito social emancipado inserido em sua comunidade, e a forma diminutiva como foi tratada não foi interpretada por ela como algo positivo, demonstrando que já possui um posicionamento sobre sua identidade, mesmo que ainda não esteja consciente, devido à idade.

A forma como a escola, juntamente com seu corpo docente e com seus funcionários, escreve seu projeto político e se posiciona em suas atividades dentro do cotidiano faz diferença na formação dessas crianças, uma vez que se posicionam criticamente sobre o mundo da vida e, consequentemente, serão mais agregadores para a comunidade, já que essas crianças fazem parte da geração futura dos Pataxó.

Segundo o portal eletrônico do Ministério do Meio Ambiente, em uma publicação sem data, que fala a respeito do Programa de Desenvolvimento Sustentável e Preservação da Mata Atlântica na Reserva Indígena Pataxó da Reserva da Jaqueira (PROJAQ), a Mata Atlântica é um dos biomas mais representativos no que diz respeito à manutenção da vida no planeta, contudo, está na lista das florestas tropicais mais ameaçadas devido a um extenso histórico de má utilização. Dessa forma, segundo o portal, são necessárias estratégias de preservação de sua biodiversidade, sustentabilidade e integração socioeconômica. Por estar localizada em um importante centro histórico e turístico nacional, o povo Pataxó fundador da Reserva da Jaqueira desenvolveu sua própria forma de integração socioeconômica, sendo perceptíveis variadas ações socioeducativas interdisciplinares e transdisciplinares que refletem nas ações da escola.

Uma escola localizada em meio à Mata Atlântica, organizada por um povo indígena que desenvolveu, ao longo dos anos, sua própria forma sustentável de trabalhar com etnoturismo, valorizando sua cultura e contribuindo com ações socioeducativas sobre o meio ambiente, com certeza, influenciaria positivamente as ações interdisciplinares e transdisciplinares da escola.

Carvalho (1998), já deixa claro e exposto a importância da interdisciplinaridade em contextos de EA, o que reforça sua aplicabilidade ao ambiente escolar da Reserva da Jaqueira. Segundo a autora, a interdisciplinaridade é colocada como um componente prático da EA "como uma concepção de mundo que supera o processo da informação compartimentada e dissociada da existência social e natural do Planeta" (CARVALHO, 1998, p. 5). 
A autora continua afirmando que a interdisciplinaridade e a EA se constituem como caminhos de abertura e renovação do ensino pela inserção do educativo no que a autora chamou de "mundo da vida", sendo este "um mergulho das práticas educativas na rede de novas sociabilidades e valores que tecem os acontecimentos sociais e históricos nos quais a vida realmente acontece" (CARVALHO, 1998, p. 5).

Esses conceitos são perfeitamente aplicáveis ao "mundo da vida" que acontece na Reserva da Jaqueira e na Escola Indígena Pataxó da Reserva da Jaqueira, pois, seguindo a explicação da autora e correlacionando-a com minhas observações, percebe-se que nesse contexto os indivíduos podem tornar-se sujeitos sociais, através de experiências educacionais engajadas nos processos de construção de uma cidadania que inclui novas sensibilidades éticas e de convivência. Ou seja, a educação que pude presenciar incentiva e colabora com a formação de sujeitos sociais engajados com o ambiente em que vivem e com a sua própria cultura, pensando nas gerações futuras e fazendo com que os alunos também tenham consciência, desde cedo, para refletir sobre as gerações futuras. É importante salientar que todas essas experiências educacionais têm caráter simples, descomplicado, linguagem apropriada e facilitada.

Isto é, faz parte do cotidiano, ao longo da formação da Reserva da Jaqueira e da inauguração da escola, o fazer educacional aplicado ao cotidiano. Isso se tornou algo tão natural quanto necessário para aqueles que estão inseridos no trabalho da escola, na administração da comunidade, na recepção dos turistas, no acompanhamento das visitas, nos rituais do pajé, nas palestras das lideranças, na construção do museu indígena, enfim, nas atividades do cotidiano do local sempre há um ato educacional, mesmo que não esteja explícito naquele momento.

Além disso, o contexto de povos indígenas que se inserem em espaços políticos para transformações sociais enquanto agentes da sua própria transformação também reflete nas ações da escola, fazendo com que a sua metodologia também, em sua maioria, insira a EA crítica. Como dizia Paulo Freire (1967, p. 63) em Educação como prática da liberdade, "O que importa, realmente, ao ajudar-se o homem é ajudá-lo a ajudar-se (e aos povos também). É fazê-lo agente de sua própria recuperação. É, repitamos, pô-lo numa postura conscientemente crítica diante de seus problemas".

A oralidade é outro aspecto importante do desenvolvimento da Jaqueira que foi incorporado nas práticas da escola, e que aqui também se encaixa nos debates sobre interdisciplinaridade e transdisciplinaridade. Pude ter acesso ao trabalho de conclusão de curso de uma das professoras da escola que atuava no Ensino Infantil da Escola da Jaqueira em 2019. A professora Ariane de Jesus dos Santos (2016) escreveu um trabalho intitulado A contação de histórias tradicionais do povo Pataxó na Reserva da Jaqueira: oralidade através dos tempos, que foi apresentado ao curso da Formação Intercultural de Educadores Indígenas da Universidade Federal de Minas Gerais. O trabalho traz a perspectiva da autora sobre a reserva e a educação feita por lá enquanto 
professora, mas também enquanto uma pessoa que viveu e cresceu na Jaqueira desde a infância. A autora começa relatando que a cultura está sempre sendo reelaborada, pois os tempos mudam e o grupo acompanha essas mudanças, já mostrando-se como agente da própria recuperação enquanto coletivo.

As ações descritas nesse trabalho falam sobre a importância da contação de história para o desenvolvimento e a essência da reserva, e a autora considera que é necessário desenvolver essa experiência dentro da escola, adaptando-a, contudo, para se tornar mais atrativa aos olhos das crianças indígenas, através de ações pedagógicas dentro da escola, para que, dessa forma, a escola seja potencializada enquanto agente fortalecedor da cultura indígena Pataxó. Segundo a autora, a contação de histórias já acontece tanto na vida e na prática da comunidade quanto na escola, pois começa a ser adaptada pelos professores para dentro da escola. Além disso, a contação de histórias também é realizada para ações educativas com os visitantes, como um momento de quebra de fronteiras. A autora-professora explica que a contação de histórias, além de ser uma forma de luta e resistência que foi se adequando à proposta curricular da escola, também é uma forma para que os moradores se vinculem com as tradições.

Dessa forma, nesse exercício de revitalização dos valores através da oralidade, o povo Pataxó está ocupando os espaços institucionais de ensino, como universidades, como uma forma de se fortalecerem enquanto grupos sociais importantes no país. A autora questiona:

Para muitas pessoas da sociedade nacional, nós nem existimos mais. Assim, me pergunto como não existimos se estamos aqui? Se somos o dono destas terras e formamos parte da história do Brasil? Vivemos na contemporaneidade dos outros povos que habitam este país? Se estamos na universidade participando do mesmo espaço e da formação que essa instituição tem como função social oferecer a todos os brasileiros? (SANTOS, 2016, p. 13)

A construção do pensamento crítico da professora enquanto sujeito social que se entende enquanto indivíduo e coletivo reflete nas ações educativas dentro do ambiente escolar. A autora compreende que a contínua resistência de anos do povo Pataxó vem da oralidade, e que a contação de história está presente no cotidiano de forma tão natural que um observador menos atento e menos sensível não perceberia. Segundo Santos, a contação de histórias está presente no convívio dentro da comunidade quando as pessoas se encontram, quando conversam sobre os filhos, as árvores, a mata, o mangue, sobre as fases da lua, quando devem preparar as mudas da planta, entre tantas atividades que, de certa forma, como salientou Carvalho (1998), buscam retecer os fios soltos do conhecimento, percebendo o mundo da vida e da interdependência dos fenômenos da natureza e da vida com sua complexidade.

No dia 23 de maio de 2019 foram registrados no diário de campo outras atividades realizadas pelo professor das turmas de $4^{\circ}$ e $5^{\circ}$ ano que demonstram algumas características do que se discutiu até agora: 
O professor das turmas de $4^{\circ}$ e $5^{\circ}$ ano instruiu os alunos para formarem grupos, e cada grupo sairia pela comunidade coletando todo lixo que encontrasse pelo caminho. Foi feita uma espécie de competição para incentivar a procura e a interação dos alunos. Vale ressaltar que escola fica no meio da reserva. A reserva possui um pátio com um grande kijeme para recepcionar turistas e para celebrações, reuniões, palestras etc. Tem espaços coletivos para cozinha, alimentação, tem várias moradias, tem o museu, que foi aberto recentemente, tem o kijeme do pajé, tem lugar para horta, e tem um kijeme que vende artesanato.

A escola fica no meio dessa estrutura, então é seguro para as crianças andarem livremente pelas moradias. Logo em seguida, após muita correria e brincadeira das crianças, cada grupo chegou com o saco cheio de descartáveis, plásticos e outros resíduos encontrados fora da lixeira na reserva. A reserva não é um lugar malcuidado, onde se encontra lixo espalhado, muito pelo contrário. Mas, uma vez ou outra acontece, e os alunos tiveram acesso às moradias além dos espaços comunitários. Em seguida, o professor pediu que classificassem o material que foi recolhido durante a busca em metal, vidro, plástico, papel e orgânico. Após essa separação, ele pediu que fizessem, então, um gráfico representando a quantidade de cada material coletado. Mais uma vez aqui o professor correlacionou disciplinas de forma interdisciplinar e transdisciplinar.

Em seguida foi proposto um debate entre os alunos, sobre de onde eles achavam que vinha esse lixo: "da escola, dos moradores ou dos turistas?". O professor incentivou os alunos a conversarem sobre essas atividades com o resto da comunidade (Diário de campo, 23 de maio de 2019, título: "Começou a Semana do Meio Ambiente").

É possível ver, nessas atividades, uma das ideias escritas por Carvalho (2005) sobre EA crítica, que é implicar os sujeitos da educação na solução, na melhoria de problemas ou na reflexão sobre conflitos através dos processos de ensino-aprendizagem que preconizem a construção de uma cidadania ambiental.

Não há necessidade de dominar a natureza, mas sim de buscar conviver de forma harmoniosa com ela, através de ações ambientais socioeducativas interdisciplinares que têm uma complexidade de intenções que vão do fortalecimento da identidade étnica do povo, de ações educativas ambientais para turistas, da convivência entre indivíduos de uma comunidade, da contação de histórias, do exercício da alteridade até o planejamento de práticas pedagógicas que salientem essas formas de perceber o mundo. 


\section{Conclusões}

Nesta seção, pretende-se fazer um resumo sobre o que foi discutido e exposto ao longo deste trabalho, considerando que as análises e interpretações já estavam sendo executadas. Em vários momentos, portanto, os resultados já foram discutidos pontualmente de acordo com o tema de que cada seção tratava. Diante do que foi observado, analisado e interpretado na pesquisa, seguindo os aspectos de análise de dados citados e diante da pergunta norteadora do projeto "As atividades de caráter socioambiental da Escola Indígena Pataxó da Reserva da Jaqueira correlacionam-se com os conceitos trazidos pela EA crítica?", identifica-se que a resposta é positiva para a grande maioria dessas atividades, e existem alguns aspectos importantes a serem relatados sobre a conclusão positiva.

Antes de começar a discorrer diretamente sobre as atividades, primeiramente é interessante relatar alguns aspectos que favorecem a resposta positiva à questão da pesquisa e que não estão necessariamente ligados a uma intenção direta por parte dos docentes. A partir do que foi observado estreitamente com a minha presença em campo, percebi que o ambiente em que a escola foi construída, juntamente com as especificidades da educação indígena, favoreceram que as mais simples atividades, vulgarmente descritas como "menos elaboradas", pudessem adquirir caráter interdisciplinar, transdisciplinar e emancipatório.

A escola está localizada em uma reserva ambiental cercada pela Mata Atlântica, o que Ihe confere uma vivência educacional diferente do que se os alunos estivessem trancafiados em uma sala quadrada de paredes brancas com enfeites de EVA, como em escolas tradicionais. O ambiente proporciona oportunidades interdisciplinares e transdisciplinares de ensino, por permitir o contato com árvores e plantas diversas, com o chão de terra, onde os alunos podem encontrar insetos variados a serem observados. Em vários momentos, enquanto participavam de jogos e brincadeiras, eles utilizavam os aprendizados trazidos dos jogos realizados no etnoturismo, dos tipos de folhas que poderiam recolher do chão para brincar e de quais outras plantas não poderiam ser recolhidas, entre outras interações possíveis e benéficas para crianças que encontram em um meio natural formas de aprendizado.

De toda forma, quero deixar claro que não estou insinuando que em ambientes tradicionais de ensino, ou seja, em construções quadradas de paredes brancas, não seja possível a prática da EA crítica, pois, se for da intenção do corpo docente, discente e do contexto escolar desenvolver o debate sobre EA crítica nesses ambientes formais, isso é possível e necessário. A questão é que pude observar, com clareza, como um ambiente escolar que não encarcera os alunos em ambientes fechados e possui espaços abertos e naturais para atividades escolares é um grande facilitador para o desenvolvimento de atividades interdisciplinares, transdisciplinares, críticas e emancipatórias.

Outro aspecto fundamental para o desenvolvimento das atividades é o formato da educação indígena. O olhar sensibilizado sobre um tipo de educação

Revbea, São Paulo, V.16, № 5: 462-499, 2021.

revista brasileira

educação ambiental 
que leva em consideração a especificidade de cada etnia e preconiza que os próprios povos sejam os formuladores e desenvolvedores da ação didáticopedagógica favorece a manutenção da cultura para gerações futuras e a afirmação de sua identidade étnica e cultural. Além disso, pude observar que a inserção de cursos de graduação intercultural para a formação de professores indígenas fomentou o desenvolvimento de professores que puderam ter acesso a uma formação profissional que incentiva o debate crítico sobre as questões culturais, históricas e políticas. Dessa forma, os próprios professores se sentiam motivados em aplicar novos debates dentro da escola e da comunidade. Além disso, essa formação profissional de professores indígenas fomentou a procura pela continuação dos estudos em cursos de capacitação, palestras e cursos de pós-graduação como mestrado e doutorado.

Faz-se necessário uma informação sobre as atividades realizadas dentro da escola: nem todas as atividades observadas possuem caráter interdisciplinar e transdisciplinar, mas algumas caracterizam-se como atividades tradicionais de alfabetização ou de cálculos, a depender da proposta do professor daquele dia. Contudo, isso não era uma constante no dia a dia da escola. Além disso, a observação do contexto geral do cotidiano dos alunos me fez interpretar essas atividades como complementares a toda uma estrutura na qual as crianças estão inseridas, vivenciando diariamente toda uma dinâmica que proporciona um ambiente de aprendizado com fortalecimento da sua cultura e construção de uma identidade em caráter emancipatório enquanto formador de sujeitos historicamente bem situados. Essa vivência se dá através dos trajes, do formato da sala de aula, da arrumação das cadeiras, das turmas multisseriadas, da língua patxohã, das brincadeiras, dos jogos, das músicas, das trilhas, dos awês. Seria injusto não os perceber enquanto emancipadores de uma educação crítica por causa de atividades que de nenhuma forma caracterizam a escola como um todo, ou seja, que não representam a escola em toda sua complexidade de ações inserida na cosmovisão de um povo.

Sobre as ações educativas de caráter socioambiental observadas, pude interpretar que se correlacionam em vários aspectos com os conceitos de EA crítica. Para justificar essa afirmação, gostaríamos de ressaltar alguns aspectos que caracterizam essas atividades a partir de dois textos que auxiliam e facilitam a compreensão dessa discussão: Santos Costa-Pinto (2005), e Carvalho (2004). Ambos os textos foram balizadores para o desenvolvimento dessa pesquisa.

Nesses dois escritos, as autoras apresentam uma lista de aspectos a serem observadas dentro da perspectiva da EA crítica, os quais observei nas atividades da Escola da Jaqueira. Segue Quadro 1 que correlaciona as atividades observadas em campo com os escritos das autoras supracitadas. 
Quadro 1: Comparativo de ações socioeducativas observadas conforme Santos e Costa-Pinto (2005).

\begin{tabular}{|c|c|}
\hline $\begin{array}{l}\text { Condições a serem observadas expostas } \\
\text { pelo texto "Potência de ação" (p. 299) }\end{array}$ & Aspectos observados em campo \\
\hline $\begin{array}{l}\text { "A adoção de uma prática pedagógica } \\
\text { não impositiva e construída de forma } \\
\text { participativa." }\end{array}$ & $\begin{array}{l}\text { Fundação e desenvolvimento da } \\
\text { escola partiram da iniciativa coletiva do povo } \\
\text { Pataxó da Reserva, incluindo a primeira } \\
\text { formulação da Proposta Pedagógica. Durante } \\
\text { o período escolar, foi observado que os } \\
\text { professores não alteram o tom de voz para } \\
\text { fazer qualquer tipo de intervenção em sala de } \\
\text { aula, além disso, incentivam a autonomia dos } \\
\text { alunos nas escolhas de atividades e o } \\
\text { desenvolvimento coletivo dessas atividades. }\end{array}$ \\
\hline $\begin{array}{l}\text { "O reconhecimento e a valorização dos } \\
\text { saberes de cada participante, entendendo } \\
\text { que o conhecimento é uma produção social e } \\
\text { coletiva." }\end{array}$ & $\begin{array}{l}\text { Foi observado o envolvimento da } \\
\text { comunidade nas atividades escolares. Pelo } \\
\text { que foi observado dentro de sala de aula, } \\
\text { nenhum aluno é forçado a se apressar em } \\
\text { suas atividades, e os alunos mais velhos são } \\
\text { incentivados a auxiliarem os alunos mais } \\
\text { novos que estão na mesma sala. Pequenas } \\
\text { conquistas são valorizadas. Além disso, } \\
\text { participam de atividades fora das salas } \\
\text { (kijemes) que contam com o envolvimento da } \\
\text { comunidade, sejam elas palestras, sejam } \\
\text { visitas a viveiros de plantas, trilhas, entre } \\
\text { outros. }\end{array}$ \\
\hline $\begin{array}{l}\text { "O estabelecimento de um espaço de } \\
\text { comunicação baseado na confiança dos } \\
\text { sujeitos que permita que eles expressem seus } \\
\text { desejos e sentimentos." }\end{array}$ & $\begin{array}{l}\text { Encontro próximo com a comunidade, } \\
\text { com as lideranças e com os familiares, } \\
\text { construindo uma rede de apoio para o } \\
\text { desenvolvimento das práticas de } \\
\text { aprendizagem. }\end{array}$ \\
\hline $\begin{array}{l}\text { "A busca por um projeto futuro } \\
\text { construído processualmente por meio da } \\
\text { reflexão, do esforço e da adesão voluntária e } \\
\text { responsável de todos os envolvidos." }\end{array}$ & $\begin{array}{l}\text { As atividades observadas dentro do } \\
\text { contexto escolar fomentam o pensamento } \\
\text { crítico a respeito da sociedade e do } \\
\text { fortalecimento da identidade indígena Pataxó, } \\
\text { além da transmissão de conhecimentos } \\
\text { tradicionais para a geração futura que } \\
\text { envolvem escola, família e comunidade. }\end{array}$ \\
\hline
\end{tabular}

No texto de Carvalho (2005), que trata da EA crítica e de seus endereçamentos, a autora aponta ideias para esse outro mundo possível (Quadro 2). 
Quadro 2: Comparativo entre ações observadas e ideias de Carvalho (2005)

\begin{tabular}{|c|c|}
\hline $\begin{array}{c}\text { Educação Ambie } \\
\text { ideias para este } \\
\text { possível ( }\end{array}$ & Aspectos observados em campo \\
\hline $\begin{array}{l}\text { "Promover a compreensão dos } \\
\text { problemas socioambientais em suas } \\
\text { múltiplas dimensões: geográficas, } \\
\text { históricas, biológicas, sociais e } \\
\text { subjetivas; considerando o ambiente } \\
\text { como o conjunto das interrelações } \\
\text { que se estabelecem entre o mundo } \\
\text { natural e o mundo social, mediado por } \\
\text { saberes locais e tradicionais, além } \\
\text { dos saberes científicos." }\end{array}$ & $\begin{array}{l}\text { A própria história da formação e do desenvolvimento } \\
\text { da Reserva da Jaqueira, que levaram à reflexão sobre } \\
\text { a construção e ao desenvolvimento de uma escola } \\
\text { dentro da reserva, passam por todas as } \\
\text { características citadas ao lado. Ao se } \\
\text { compreenderem como um coletivo, os Pataxó } \\
\text { reivindicaram seu território a partir de uma postura } \\
\text { política que também se configurava como postura } \\
\text { socioambiental de preservação do meio ambiente e } \\
\text { da diversidade cultural dos povos indígenas. A Escola } \\
\text { da Jaqueira funciona como um agente fortalecedor e } \\
\text { incentivador das reflexões das questões } \\
\text { socioambientais para gerações futuras. }\end{array}$ \\
\hline $\begin{array}{l}\text { ir para a transformação dos } \\
\text { drões de uso e distribuição } \\
\text { ambientais em direção a } \\
\text { nais sustentáveis, justas e } \\
\text { de vida e de relação com a }\end{array}$ & $\begin{array}{l}\text { O resgate pela forma de viver ancestral é uma forma } \\
\text { de transformação que busca maneiras sustentáveis e } \\
\text { harmoniosas de conviver com o meio ambiente. Além } \\
\text { disso, a comunidade da Reserva da Jaqueira, desde } \\
\text { o desenvolvimento do reserva, teve encontros com } \\
\text { grupos, associações e órgãos não governamentais } \\
\text { que auxiliaram nos debates sobre sustentabilidade } \\
\text { que culminaram no desenvolvimento das atividades } \\
\text { de etnoturismo, uma forma educacional e } \\
\text { emancipatória de sustento que se reflete nas ações e } \\
\text { atividades desenvolvidas na escola. }\end{array}$ \\
\hline $\begin{array}{l}\text { "Formar uma atitude ecológica } \\
\text { dotada de sensibilidades estéticas, } \\
\text { éticas e políticas sensíveis à } \\
\text { identificação dos problemas e } \\
\text { conflitos que afetam o ambiente em } \\
\text { que vivemos." }\end{array}$ & $\begin{array}{l}\text { A proximidade dos debates levantados pela } \\
\text { comunidade e pela liderança da reserva, } \\
\text { principalmente com sua inserção nos ambientes } \\
\text { acadêmicos, proporcionou atitudes de sensibilização } \\
\text { quanto às questões socioambientais, principalmente } \\
\text { no âmbito escolar, no qual escola, família e } \\
\text { comunidade têm relação de diálogo aberta e próxima. }\end{array}$ \\
\hline $\begin{array}{l}\text { "Implicar os sujeitos da educação } \\
\text { com a solução ou melhorias destes } \\
\text { problemas ou conflitos através de } \\
\text { processos de ensino-aprendizagem, } \\
\text { formais ou não-formais, que } \\
\text { preconizem a construção significativa } \\
\text { de conhecimentos e a formação de } \\
\text { uma cidadania ambiental." }\end{array}$ & $\begin{array}{l}\text { A atividades de etnoturismo desenvolvidas na reserva } \\
\text { são atividades educacionais que sensibilizam ao meio } \\
\text { ambiente e ao modo de vida do povo indígena Pataxó. } \\
\text { Dessa forma, as atividades observadas em } \\
\text { determinados momentos na escola demonstram que } \\
\text { existe a preocupação em levantar debates reflexivos } \\
\text { sobre os cuidados com a reserva, sobre a formação } \\
\text { dos estudantes enquanto sujeitos conhecedores e } \\
\text { orgulhosos de seus costumes e história. }\end{array}$ \\
\hline $\begin{array}{l}\text { "Atuar no cotidiano escolar e não } \\
\text { escolar, provocando novas questões, } \\
\text { situações de aprendizagem e } \\
\text { desafios para a participação na } \\
\text { resolução de problemas, buscando } \\
\text { articular escola com os ambientes } \\
\text { locais e regionais onde estão } \\
\text { inseridas." }\end{array}$ & $\begin{array}{l}\text { A Escola Indígena Pataxó da Reserva da Jaqueira } \\
\text { realiza atividades no espaço da escola e por toda } \\
\text { comunidade. Aliás, é muito difícil conceber a escola } \\
\text { como instituição desligada do restante da } \\
\text { comunidade da reserva. De certa forma, tanto escola } \\
\text { quanto comunidade se correlacionam e se } \\
\text { complementam nas atividades educacionais. }\end{array}$ \\
\hline
\end{tabular}

Continua... 
...continuação.

\begin{tabular}{|c|c|}
\hline $\begin{array}{c}\text { Educação Ambiental Crítica: } \\
\text { ideias para este outro mundo } \\
\text { possível (p. 21) }\end{array}$ & Aspectos observados em campo \\
\hline $\begin{array}{lcr}\text { "Construir } & \text { processos } & \text { de } \\
\text { aprendizagem } & \text { significativos, } \\
\text { conectando a experiência e os } \\
\text { repertórios já existentes com } \\
\text { questões e experiências que possam } \\
\text { gerar novos conceitos e significados } \\
\text { para quem se abre à aventura de } \\
\text { compreender e se deixar surpreender } \\
\text { pelo mundo que o cerca." }\end{array}$ & $\begin{array}{l}\text { Esse ponto citado ao lado toca em um dos assuntos } \\
\text { mais pertinentes sobre a formação da reserva e, } \\
\text { consequentemente, da escola, uma vez que foi } \\
\text { preciso um processo de reconstrução do modo de } \\
\text { viver indígena Pataxó a partir da oralidade do que foi } \\
\text { resgatado pelos anciões, mas também pelo processo } \\
\text { de aprendizado e adaptação de costumes aprendidos } \\
\text { com outras etnias, como os Maxakali. }\end{array}$ \\
\hline $\begin{array}{l}\text { "Situar o educador como, sobretudo, } \\
\text { um mediador de relações } \\
\text { socioeducativas coordenador de } \\
\text { ações, pesquisas e reflexões } \\
\text { escolares e/ou comunitárias que } \\
\text { oportunizem novos processos de } \\
\text { aprendizagens sociais, individuais e } \\
\text { institucionais." }\end{array}$ & $\begin{array}{l}\text { Em observação participante, pude perceber que os } \\
\text { professores da Escola da Jaqueira usam estratégias } \\
\text { didático-pedagógicas nas quais os alunos se sentem } \\
\text { muito à vontade de estarem naqueles espaços, se } \\
\text { sentindo pertencentes a eles. Além disso, não percebi } \\
\text { uma postura intimidadora, pois, nos dias em que } \\
\text { estive presente, houve uma mediação do aprendizado } \\
\text { através da busca do atendimento pessoal a cada } \\
\text { aluno, na medida do possível. Além disso, a } \\
\text { autonomia dos alunos é incentivada no processo de } \\
\text { escolha da continuação das atividades propostas } \\
\text { pelos professores. }\end{array}$ \\
\hline
\end{tabular}

Em síntese, compreendo os processos didático-pedagógicos realizados na Escola Indígena Pataxó da Reserva da Jaqueira, em sua maioria, como críticos e emancipatórios. Digo "em sua maioria", pois, nos momentos de observação participante, percebiam-se algumas atividades de caráter formal e tradicional, o que já foi contextualizado anteriormente. Contudo, isso não deslegitima o esforço contínuo do corpo docente da escola em pesquisar atividades que fomentem o diálogo e a reflexão sobre questões socioambientais pertinentes à Reserva da Jaqueira e às suas especificidades, uma vez que alguns dos principais objetivos da escola são o fortalecimento da cultura Pataxó, a manutenção e o resgate de seus costumes, a adaptação a novas questões socioambientais sem perder as características do resgate de sua ancestralidade. Principalmente, a escola funciona como um ambiente de transmissão de conhecimentos às novas gerações, garantindo a elas o direito à territorialidade, à sua identidade, à dignidade e à manutenção dos costumes e tradições de um povo tão emblemático e importante para estabelecer debates verdadeiros sobre EA crítica e sociedades sustentáveis.

\section{Agradecimentos}

À Universidade Federal do Sul da Bahia, à Reserva Indígena Pataxó da Reserva da Jaqueira e à Escola Indígena Pataxó da Reserva da Jaqueira e suas lideranças, professores e demais responsáveis pelo funcionamento da escola, à Nitynawã Pataxó, Sirleide Pataxó, Sinoeme Pataxó, Ariane Pataxó. 


\section{Referências}

ANDRADE, D.F.; SORRENTINO, M. Da gestão ambiental à Educação Ambiental: as dimensões subjetivas e intersubjetiva nas práticas de Educação Ambiental. Pesquisa em Educação Ambiental, São Paulo, v. 8, n. 1, p. 88-98, 2013.

BAHIA. Secretaria do Meio Ambiente/Diretoria de Educação Ambiental para a Sustentabilidade. Política Estadual de Educação Ambiental. Lei no 12.056 de 07 de janeiro de 2011. Salvador, 2011. Disponível em: <https://governoba.jusbrasil.com.br/legislacao/1026482/lei-12056-11>. Acesso: 13 maio 2020.

BARTH, Fredrik. 0 guru, 0 iniciador e outras variações antropológicas. Tradução de John Cunha Comerford. Rio de Janeiro: Contra Capa, 2000.

BRASIL. Presidência da República. Política Nacional de Educação Ambiental. Lei n 9.795 de 27 de abril de 1999. Brasília, 1999. Disponível em: <http://www.planalto.gov.br/ccivil 03/leis/19795.htm>. Acesso em: 2 jun. 2021.

BORGES, L. da S. .; SILVA, J. B. do C.; RODRIGUES, D. . do S. Educação Ambiental e cultura quilombola: entre ausências de políticas públicas e práticas de resistência. Revista Brasileira de Educação Ambiental, v. 16, n. 1, p. 430449, 2021.

BRASIL. Tratado de Educação Ambiental para sociedades sustentáveis e responsabilidade global. Disponível em: $<$ http://portal.mec.gov.br/secad/arquivos/pdf/educacaoambiental/tratado.pdf>. Acesso em: 19 nov. 2020.

CARVALHO, I.C.M. Educação Ambiental crítica: nomes e endereçamentos da educação. In: LAYRARGUES, P.P. (Org.). Identidades da Educação Ambiental brasileira. Brasília: Ministério do Meio Ambiente, 2004.

CARVALHO, I.C.M. Educação para sociedades sustentáveis e ambientalmente justas. Revista Eletrônica Mestrado em Educação Ambiental, Ed. Especial, 2008.

CARVALHO, I.C.M. Em direção ao mundo da vida: interdisciplinaridade e Educação Ambiental. Brasília: IPÊ - Instituto de Pesquisas Ecológicas, 1998.

CASTRO, M.S.M. A Reserva Pataxó da Jaqueira: o passado e o presente das tradições. 2008. 137 f. Dissertação (Mestrado em Antropologia Social) - Instituto de Ciências Sociais, Universidade de Brasília, Brasília, 2008.

CAVALLO, G.A. Conhecimentos ecológicos indígenas e recursos naturais: a descolonização inacabada. Estudos avançados, São Paulo, v. 32, n. 94, p. 373390, 2018.

COSTA-PINTO, A.B.; RODRIGUES, L. Reflexões sobre a educação em Espinosa: a experiência do encontro como segundo nascimento. Filosofia e Educação, Campinas, v. 5, n. 1, p. 111-129, 2013. 
CRUZ, F.S.M. Indígenas Antropólogos e o Espetáculo da Alteridade. Revista de estudos e pesquisas sobre as américas, Brasília, v. 11, n. 2, 2017.

DUTRA, J.C.O.; MAYORGA, C. Mulheres Indígenas em Movimentos: Possíveis Articulações entre Gênero e Política. Psicologia, Ciência e Profissão, Brasília, v. 39, p. 113-129, 2019.

FERRARO JÚNIOR, L.A. (Org.). Encontros e caminhos: formação de Educadoras(es) Ambientais e Coletivos Educadores. Brasília: Ministério do Meio Ambiente, 2005.

FOLADORI, G. Avanços e limites da sustentabilidade social. Revista Paranaense de Desenvolvimento, Curitiba, n. 102, p.103-113, 2002.

FOLADORI, G.; TAKS, J. Um olhar antropológico sobre a questão ambiental. MANA, Rio de Janeiro, v. 10, n. 2, p. 323-348, 2004.

FREIRE, P. Educação como prática da liberdade. Rio de Janeiro: Paz e Terra, 1967.

FREIRE, P. Pedagogia da autonomia: saberes necessários à prática educativa. São Paulo: Paz e Terra, 1996.

GUIMARÃES, M.; MEDEIROS, H.Q. Outras epistemologias em Educação Ambiental: o que aprender com os saberes tradicionais dos povos indígenas. REMEA - Revista Eletrônica do Mestrado em Educação Ambiental, Ed. Especial, p. 50-67, 2016.

HAGUETTE, T.M.F. Metodologias qualitativas na sociologia. 5 . ed. Petrópolis: Vozes, 1997.

KAIPPER, M.D. Aragwaksã: a retomada da terra, a festa de casamento e outras manifestações culturais indígenas pataxó na Reserva da Jaqueira, Porto Seguro, Bahia. 195 f. 2018. Tese (Doutorado História) - Universidade do Vale do Rio dos Sinos, São Leopoldo, 2018.

LITTLE, P.E. Territórios sociais e povos tradicionais no brasil: por uma antropologia da territorialidade. Anuário Antropológico, Brasília, v. 28, n. 1, p. 251-290, 2003.

LÜDKE, M.; ANDRÉ, M.E.D.A. Pesquisa em educação: abordagens qualitativas. São Paulo: EPU, 1986.

LOPES, A. (Org.). Educação Ambiental. Brasília: Senado Federal, Coordenação de Edições Técnicas, 2015.

MACAGNO, L. O dilema multicultural. Curitiba, Editora UFPR, 2014.

MELIÀ, B. Educação indígena na escola. Cadernos Cedes, Campinas, n. 49, p. 10-17, 1999.

MELLO, S.S.; TRAJBER, R. (Orgs.) Vamos cuidar do Brasil: conceitos e práticas em Educação Ambiental na escola. Brasília: MMA/UNESCO, 2007. 
MINAYO, M.C.S.; ASSIS, S.G.; SOUZA, E.R. (Orgs.). Avaliação por triangulação de métodos: Abordagem de Programas Sociais. Rio de Janeiro: Editora Fiocruz, 2005.

MINAYO, M.C.S. Análise qualitativa: teoria, passos e fidedignidade. Ciência \& saúde coletiva, Rio de Janeiro, v. 17 n. 3, 2012.

MINAYO, M.C.S. (Org.). Pesquisa Social. Teoria, método e criatividade. Petrópolis: Vozes, 2013.

MORIN, E. Os sete saberes necessários à educação do futuro. Tradução de Catarina Eleonora F. da Silva e Jeanne Sawaya. 5. ed. São Paulo: Cortez, 2000.

NEVES, S.C. Eficácia ritual e eficácia turística: o ritual do awê entre os pataxó meridionais e o turismo. CULTUR, Ilhéus, v. 04, n. 02, p. 92-103, 2010.

OLIVEIRA, J.P. Uma etnologia dos "índios misturados"? Situação colonial, territorialização e fluxos culturais. MANA, Rio de Janeiro, v. 4, n. 1, p. 47-77, 1998.

PACHECO, J.O. Identidade cultural e alteridade: problematizações necessárias. Spartacus - Revista eletrônica dos Acadêmicos do Curso de História da UNISC, 2004.

PATAXÓ, N. Yêp Xohã Ui Awakã Pataxó (As guerreiras na história Pataxó). Rio de Janeiro: Museu do índio - FUNAI, 2011.

PATAXÓ, P. Inventário Cultural Pataxó: tradições do povo Pataxó do Extremo Sul da Bahia: Atxohã. Instituto Tribos Jovens (ITJ), 2011. Disponível em: $<$ https://docplayer.com.br/55946537-Inventario-cultural-pataxo.html>. Acesso em: 19 nov. 2020.

PORTO SEGURO. Política Municipal de Educação Ambiental de. Disponível em:

$<$ http://www.portoseguro.ba.io.org.br/contasPublicas/download/669823/621/201 4/7/publicacoes/BEAB1A17-E062-370C-A853A08F507976E5.pdf>. Acesso em: 2 jun. 2021.

PORTO, H.T.; BONIN, J.A. A educação indígena Pataxó: entre distopias e utopias. Tellus, Campo Grande, v. 20, n. 41, p. 101-128, 2020.

POUTIGNAT, P.; STREIFF-FENART, J. Teorias da etnicidade. Seguido de Grupos Étnicos e suas Fronteiras, de Frederic Barth. Tradução de Elcio Fernandes. São Paulo: Fundação Editora da UNESP, 1998.

PREDES, I.A. Grafismo corporal indígena pataxó: um estudo na aldeia de Coroa Vermelha e Reserva da Jaqueira. 2011. 136 f. Dissertação (Mestrado em Desenho, Cultura e Interatividade) - Universidade Estadual de Feira de Santana, Feira de Santana, 2011.

RIBEIRO, B.G. Arte indígena, linguagem visual. Ensaios de opinião, Rio de Janeiro, p. 101-110, 1978. 2020. 
RIBEIRO, D.B.; SOUSA, A.C.; CRUZ, T.V.; LEITE, A.B.; SANTOS, V.V. A trilha da Reserva Pataxó da Jaqueira como instrumento de educação socioambiental para estudantes de nível médio. Educação Ambiental em Ação, Novo Hamburgo, v. 17, n. 65, 2018.

SANTOS, A.J. A contação de histórias tradicionais do Povo Pataxó na Reserva da Jaqueira: a oralidade através dos tempos. 2016. $57 \mathrm{f}$. Trabalho de Conclusão de Curso (Licenciatura em Línguas, Artes e Literatura) - Faculdade de Educação, Universidade Federal de Minas Gerais, Belo Horizonte, 2016.

SANTOS TUPINAMBÁ, M.V.A. Práxis pedagógicas e saberes culturais: diálogos com as professoras Tupinambá de Olivença. 2016. 137 f. Dissertação (Mestrado Profissional em Educação) - Universidade Estadual de Santa Cruz, llhéus, 2016.

SANTOS, M.N.C.A. (NITYNAWÃ). 2018. 60 f. Histórias da Reserva da Jaqueira: experiências de autogestão em etnoturismo. Monografia (Licenciatura Intercultural Indígena) - Instituto Federal da Bahia, Porto Seguro, 2018.

SILVA, Rosana L. F. 0 meio ambiente por trás da tela: concepções de Educação Ambiental dos filmes da TV Escola. São Paulo: USP, 2007. Disponível em: <https://anped.org.br/sites/default/files/gt22-3678-int.pdf>. Acesso em: 19 nov. 2020.

THIOLENTT, M. Metodologia da pesquisa-ação. São Paulo: Cortez, 1986.

TRINDADE, R.N. A internacionalização dos direitos humanos dos povos indígenas na ótica da resistência Pataxó no sul da Bahia entre 1951 e 2017. Artigo de Conclusão de Curso (Bacharelado em Relações Internacionais) UNINTER, 2018. Disponível em: <https://repositorio.uninter.com/handle/1/212>. Acesso em: 19 nov. 2020. 